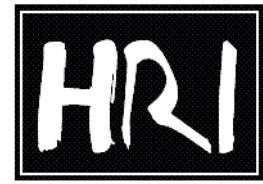

THE HUMAN RIGHTS INSTITUTE

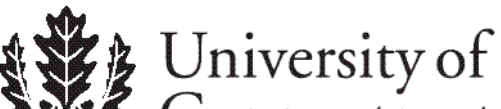

$4 \%$ Connecticut

Economic Rights Working Paper Series

\title{
Economic and Social Rights Fulfillment Index: Country Scores and Rankings
}

Susan Randolph

University of Connecticut

Sakiko Fukuda-Parr

The New School

Terra Lawson-Remer

The New School

Working Paper 11

September 2009

The Human Rights Institute University of Connecticut Thomas J. Dodd Research Center 405 Babbidge Road, U-1205 Storrs, CT, 06269, USA

Email: humanrights@uconn.edu

Tel: 860-486-8739

Fax: 860-486-6332

http://www.humanrights.uconn.edu/ 


\begin{abstract}
Building on previously proposed methodology for an index of economic and social rights fulfillment, this paper presents country scores and rankings based on the Economic and Social Rights Fulfillment Index (ESRF Index). Unlike socio-economic indicators, which are often used as proxies for the extent to which rights-holders enjoy economic and social rights, the ESRF Index incorporates the perspective of the duty-bearer as well as the rights-holder, and takes into account the concept of progressive realization. The resulting scores and rankings provide important new information that complements other measures of economic and social rights fulfillement. The ESRF Index is an important conceptual an methodological breakthrough although is still does not capture all key human rights principles, such as the right to non-discrimination and equality. The paper also analyzes the results of the global ranking and outlines some priorities for further research.
\end{abstract}

Keywords: Human Rights; Economic and Social Rights; Human Development; Economic Development; Measurement; Progressive Realization; Inequality; Global Ranking.

The Economic Rights Working Paper Series of the University of Connecticut Human Rights Institute is an effort to gather the most recent work on Economic Rights. This paper is work in progress. The authors remain copyright holders of this paper.

This working paper is indexed on RePEc, http://repec.org/ 


\title{
Economic and Social Rights Fulfillment Index: Country Scores and Rankings
}

\author{
By Susan Randolph, Sakiko Fukuda-Parr, and Terra Lawson-Remer
}

\section{Introduction}

In a previous paper in this journal (Fukuda-Parr, Lawson-Remer, and Randolph, 2009), we presented a concept and methodology for a new approach to measuring the level of economic and social rights fulfillment, and proposed a composite index, the Economic and Social Rights Fulfillment Index (ESRF Index). While the concept of rights fulfillment includes both the right holders' enjoyment of rights as well as the duty bearers' compliance with obligations, measurement of economic and social rights relies increasingly on socio-economic indicators which reflect only one of these perspectives, that of the rights holder. The ESRF Index addresses this weakness and incorporates both perspectives. The Index further takes account of the principle of progressive realization arising from the fact that human rights fulfillment depends in part on state capacity including resources and institutional strengths.

This paper presents the results of the ESRF Index for the world -- including country scores and rankings -- and incorporates several methodological refinements to the original index methodology. It also undertakes an analysis of the results, and suggests priorities for further research. The results show a global pattern of state performance that ranges widely among countries. No country fully meets its obligations for the progressive realization of all economic and social rights, although some countries nearly do so. Other countries fall far short of meeting any of their economic and social rights obligations. The results reveal serious failures even in some very well endowed countries, and find state performance in economic 
and social rights fulfillment does not depend on income. Our index responds to the often heard concern of human rights advocates that the principle of progressive realization is undefined, thus providing an 'escape hatch' for low income states reluctant to comply with their obligations. The ESRF Index empirically defines the obligations of progressive realization as the maximum achieved globally at the country's level of income, and thus closes the hatch. We will explore the relationship between resources and human rights obligations in a follow up paper.

The results differ substantially from measures that only take into account the rightsbearer perspective, notably the HDI, and demonstrate that the ESRF Index provides significant new information for human rights assessment. The findings highlight the usefulness of the ESRF Index as one among a toolkit of diverse measurement tools that can be used in human rights assessment. While a number of human rights indicators are being proposed, many are qualitative. The central limitation of qualitative measures is comparability but these indicators reveal information on process and structural dimensions. The ESRF Index is highly complementary to these qualitative indicators.

The paper starts with a step by step description of the methodology. The next section presents the scores and rankings. The rest of the paper analyses the findings in three ways: as a description of the state of the economic and social rights fulfillment across countries; in terms of the policy implications; and as an assessment of the ESRF Index as a measurement tool. The final section draws out our conclusions and suggests priorities for further research. 


\section{Methodology}

The core Economic and Social Rights Fulfillment Index, ESRF1, (Fukuda-Parr, et al, 2009) takes into account five core economic and social rights: the right to food, education, health, adequate housing, and decent work. A separate index for high income OECD countries, ESRF2, is proposed that uses indicators that are more meaningful in the context of countries with advanced economic and social development. Given data limitations, the ESRF-2 only takes into account four core rights: the right to food, education, health, and decent work. Table 1 shows the specific indicators used to measure enjoyment of particular rights for both our core (ESRF1) and supplementary (ESRF-2) indices. ${ }^{1}$

Our concept and methodology paper (Fukuda-Parr et al 2009), explored several alternative methodologies of calculation for the ESRF Index. In this paper we use the Achievement Possibility Approach specified as Version 2B in that paper. This approach assesses the extent to which a country is meeting its obligation of progressive realization as the percentage of the feasible level of achievement given the country's resources and imposes a penalty on countries with resources sufficient to fully realize a given right but failing to do so.

\section{Review of Achievement Possibilities Frontier Methodology}

The Achievement Possibilities Frontier (APF) approach constructs an APF for each indicator that specifies the value of the indicator that can feasibly be achieved at each per capita income level. To do so, first using data from all countries for all years between 1990 and 2006 we plot the scatter of the indicator value, $x$, against per capita GDP in 2005 PPP\$. We then estimate the functional relationship defining the outer envelope of the scatter plot: $x_{\max }=f(y)$, where $x_{\max }$ is a value of $x$ on the outer envelope of the scatter plot. The scatter 
plots and resultant Achievement Possibilities Frontiers are shown as figures 1-3; figure 1 shows the APFs for those indicators only used in the construction of our core index, ESRF-1, figure 2 shows the APFs for the indictors used in common by ESRF-1 and ESRF-2, while figure 3 shows the APFs used only in the construction of our secondary index, ESRF-2. ${ }^{2}$

\section{[FIGURES 1 THROUGH 3 ABOUT HERE]}

The estimated frontiers show for each per capita GDP level the value of the indicator that could be achieved, given the state of knowledge regarding the social-economic policies that best promote economic and social rights. While this "technology" might be expected to change over the long-run, it is expected to be reasonably stable over the short to medium term. This feature enables valid comparisons over time of the extent to which economic and social rights obligations are being met, a feature essential to evaluating whether the principle of nonretrogression is upheld. Table 1 shows the country/year observations defining the frontier for each indicator. The years corresponding to the frontier observations range from 1990 to 2006 with no pronounced tendency to bunch in the 2005-2006 period, as is consistent with our goal of defining a frontier that is stable over the short to medium term.

\section{[TABLE 1 ABOUT HERE]}

Table 2 shows the equations corresponding to each of the Achievement Possibilities Frontiers along with their peak indicator value, $\mathrm{Xp}$, and the income level when the peak indicator value is initially reached, the Yp value. The per capita income level corresponding to the peak indicator value, Yp, differs across indicators as does the shape of the frontiers, reflecting differences in the feasibility of transforming resources into different aspects of rights fulfillment. For example, a primary school completion rate of $100 \%$ can be achieved at a per 
capita income level of $\$ 1,076$ (2005 PPP) while a per capita income level of $\$ 22,190$ is necessary to achieve the peak math and science scores on the Programme for International Student Assessment (PISA) tests, reflecting the greater ease of transforming resources into school access than school quality. Three of the indicators for our supplementary indicator, ESRF-2, fail to show any sensitivity to income over the per capita income range concerned: percentage of infants with normal birth weight; percentage of the population with income greater than $50 \%$ of median income; and percentage of labor force not long term unemployed. In these cases, the peak value of the indicator, $X p$, is set at the highest value achieved by any OECD high income country, and the Yp value is set at $\$ 16,000$ (2005 PPP), the income level breakpoint differentiating high income countries from upper middle income countries. ${ }^{3}$

\section{[TABLE 2 ABOUT HERE]}

\section{Refinements to the Achievement Possibilities Approach}

As explained in our previous paper (Fukuda-Parr, et al, 2009), the ESRF Index is constructed by aggregating indices for each of the separate indicators. Thus the first step is to construct the index for each indicator. The next step is to specify the index value as the percentage of the indicator value that could be achieved, given the country's per capita income level. The third step is to adjust these values for countries with incomes sufficient to realize the maximum indicator value, $\mathrm{Xp}$, but which fail to do so. The index value for these countries is the actual percentage achievement minus a penalty. A number of alternative penalty formulas were explored and compared using an axiomatic approach in our previous paper. Here, we refine our methodology in two regards. First, we adjust the indicator scores to take into account differences between the theoretical and practical minimum indicator values. Second, 
we utilize a slightly modified version of our preferred penalty formula, formula F, which conforms to ex ante criteria regarding an appropriate penalty.

Although all of the indicators have a minimum theoretical value of zero, the practical minimum value often exceeds zero by a substantial amount, as table 1 shows. For example, the child survival rate never falls below $68 \%$ in any country over the 1990 to 2006 period. On the other hand, the observed percentage of births assisted ranges from $5 \%$ to $100 \%$. The result is that indicators exhibiting a wider range between their maximum and minimum values inappropriately drive the aggregated index, even if the underlying indicators are explicitly weighted equally. In the above example, the percentage of births assisted drives the health index component of our core indicator if the three health indices are simply averaged. To overcome this bias, we rescale the index value using the following formula:

100 (observed $x$ - minimum value $x$ ) / (frontier value $x$ - minimum value $x$ ), where the minimum value of indicator $\mathrm{x}$ is the minimum observed for any country over the 1990-2006 period and approximates the value one would expect to observe in a failed state with a subsistence per capita income level and no priority given to ensuring economic and social rights. Figure 4 illustrates how the rescaling formula works.

[FIGURE 4 ABOUT HERE]

Our previous paper (Fukuda-Parr, et al, 2009) considered seven possible formulas (formulas A-G) to exact a penalty on countries with the resources necessary to realize the maximum value of an indicator, but which fail to do so. Formula F stood out as meeting all the desirable criteria except one, flexibility. As initially specified, it did not include a parameter 
that can be adjusted to reflect alternative penalty rates. Formula $\mathrm{F}$ as initially specified is:

$$
X^{*}=100\left[(x / 100)^{(Y / Y p)}\right]
$$

where $\mathrm{x}$ is the indicator value (or the rescaled indicator value if rescaling as discussed above), $\mathrm{Y} / \mathrm{Yp}$ is the ratio of the country's per capita GDP to the per capita income level at which $\mathrm{x}$ reaches its maximum value, and $x^{*}$ is the adjusted index value. Note that since the adjustment formula is only applied when $Y>Y p$, the ratio $Y / Y p$ will always be greater than 1 . To remedy the failure of the "Flexibility" criterion, in the above formula, we raise the ratio $\mathrm{Y} / \mathrm{Yp}$ to the power of $\beta$. If $\beta=1$, then the adjustment formula is as specified above. If $\beta>1$, then the penalty is increased, while if $\beta<1$ it is decreased. The resultant penalty formula is specified below, setting $\beta=.5$, our preferred variant of Formula $F$.

$$
\mathrm{x}^{*}=100\left[\left(\frac{x}{100}\right)^{\left(\frac{Y}{Y p}\right)^{.5}}\right]
$$

Figure 5 compares the resultant adjusted index values for $\beta=1$ and $\beta=.5$ for different values of $x$. The dark lines show the penalty for $\beta=.5$, while the dotted lines show the penalty for $\beta=1$. In either case, if the country's score (raw or rescaled) on an indicator is $100 \%$ of the peak value of the indicator, its index value is $100 \%$ regardless of how high its income becomes. If a country achieves only $95 \%$ of the peak indicator value, as income increases to 10 times the Yp value, the index score falls from 95 to $60 \%$ if $\beta=1$, but only to $85 \%$ if $\beta=.5$. If a country achieves only $90 \%$ of the peak indicator value, as income increases to 10 times the Yp value its index score falls from $90 \%$ to $35 \%$ if $\beta=1$, but only to $70 \%$ if $\beta=.5$. If a country achieves only $50 \%$ of the peak indicator value, if $\beta=1$, the index score decreases to $10 \%$ as income increases to 10 times the Yp value, but if $\beta=.5$, the index score reaches $0 \%$ by the time income increases to 8 times the Yp value. 


\section{[FIGURE 5 ABOUT HERE]}

Once the indices for each indicator have been computed the rights indices are aggregated by averaging the relevant indicator indices. Finally, the individual economic and social rights indicators are aggregated into the ESRF-1 and ESRF-2 using the following formulas:

ESRF-1 $=\left[\left(\text { Food Index }_{1}{ }^{1 / \alpha}+\text { Education Index }_{1}{ }^{1 / \alpha}+\text { Health Index }_{1}{ }^{1 / \alpha}+\text { Housing Index }_{1}{ }^{1 / \alpha}+\text { Work }^{\text {Index }}{ }^{1 / \alpha}\right) / 5\right]^{\alpha}$ ESRF-2 $=\left[\left(\text { Food Index } 2{ }^{1 / \alpha}+\text { Education Index }_{2}{ }^{1 / \alpha}+\text { Health Index }_{2}{ }^{1 / \alpha}+\text { Work Index }_{2}{ }^{1 / \alpha}\right) / 4\right]^{\alpha}$ The subscripts 1 and 2 refer to rights indices constructed for our main index, ESRF-1, and our supplementary index for OECD high income countries, ESRF-2, respectively. The value of alpha, $\alpha$, determines the weight placed on rights dimensions where fulfillment falls shortest. In our analysis, we set $\alpha=1$ such that we weight all rights dimensions equally. If one computes the ESRF indices setting $\alpha>1$, then a higher weight is placed on the rights dimensions where fulfillment falls shortest. Schematic diagrams demonstrating the steps in the construction of ESRF-1 and ESRF-2 are shown in figures 6 and 7 respectively.

\section{[ FIGURES 6- AND 7 ABOUT HERE]}

\section{Findings: State of Economic and Social Rights Fulfillment}

Descriptive statistics for ESRF-1 and ESRF-2 are shown in tables 3 \& 4. Each table is comprised of two panels. Panel A shows the descriptive statistics for all countries that have data sufficient to calculate the index for at least one of the rights. Panel B shows the descriptive statistics for countries that have data sufficient to calculate the index for all of the rights. Table 5 provides the country scores on the individual rights indices as well as the aggregate ESRF-1 Index, while table 6 does the same with reference to the ESRF-2 Index for OECD high income countries. 
Both tables rank the countries from best (1) to worst performance with regard to meeting their overall economic and social rights obligations. Only countries for which all of the component rights indices can be computed are ranked, but countries for which one or more of the component rights indices could be calculated are included at the end of the table. The most recent observations available as of June, 2009 were used to calculate the indices and generally referred to the years 2007 back to 2000. Although 2007 GDP per capita is shown in tables 5 \& 6, per capita GDP data for each country were matched by year to each indicator. ${ }^{4}$ With regard to our main index, ESRF-1, it is possible to calculate the health, education, and housing component right-indices for the largest number of countries, 150, 149 and 149, respectively. In contrast, the component-indices for the rights to decent work and food can only be calculated for 112 countries. Data are only sufficient to calculate all 5 rights indices for 101 non-OECD high income countries. It is possible to calculate the ESRF-2 scores for 24 high income OECD countries and all but one component right index for an additional four high income OECD countries.

\section{[TABLES 3 THROUGH 6 ABOUT HERE]}

The ESRF Index provides an evidence based assessment of the extent to which states are complying with their obligations to their citizens under the International Covenant on Economic, Social and Cultural Rights, ICESCR (United Nations General Assembly, 1966). In interpreting the results, it should be recalled that the scores capture average achievement of the country relative to the resources available, since in order to evaluate the efforts made towards the progressive realization of economic and social rights as required under the ICESCR: 
Each State Party to the present Covenant undertakes to take steps, individually and through international assistance and co-operation, especially economic and technical, to the maximum of its available resources, with a view to achieving progressively the full realization of the rights recognized in the present covenant by all appropriate means, including particularly the adoption of legislative measures. (Article 2, paragraph 1). The ESRF scores thus reflect the policy response including both the level of political will and the relative effectiveness of the policies adopted in the context of the external constraints that are faced.

None of the countries for which the ESRF Index can be calculated fully meets its obligations with regard to all five of the rights simultaneously. The best performing country on the ESRF-1 index, Guyana, achieves a score of just over $96 \%$, indicating that it fulfills $96 \%$ of its aggregate obligation across all rights; the best performing OECD high income country, Finland, meets just under $95 \%$ of its aggregate obligation across all rights.

The contrast across countries is stark. The worst performing country, Equatorial Guinea, only meets $16 \%$ of its overall obligation. The results show a large number of countries-rich and poor-falling far short of meeting their economic and social rights obligations. Among nonOECD high income countries, the average of the poorest performing five countries falls at or below $20 \%$ of the obligation met on the rights to work, food, and education. Even among the high income OECD countries, the poorest performing 5 high income OECD countries meet only $65 \%$ of their obligation with regard to the right to decent work and not quite $75 \%$ of their obligation with regard to the right to education. Most countries have the necessary resources to substantially increase the realization of economic and social rights; on average, the 101 
countries for which the ESRF-1 index can be calculated meet only $72 \%$ of their obligation. Average performance is somewhat better regarding the right to health (78\%) and somewhat worse regarding the rights to food and education (both 66\%). High income OECD countries do better on average, but still fall substantially short of the mark meeting only $88 \%$ of their combined ESR obligations. Like the ESRF-1 countries, they come closest to meeting their obligations with regard to the right to health, (nearly 97\%). Unlike the ESRF-1 countries, high income OECD countries' average performance is worst with regard to the right to decent work. The standardized coefficients from regressions of the ESRF indices on their component rights indicators reveal the right to education is the most important driver of the ESRF-1 Index, while the right to work is the most important driver of the ESRF-2 Index. All of the individual rights indices, however, substantially influence the aggregate index in both the case of ESRF-1 and ESRF-2.

Turning to comparison among different economic and social rights, some rights are fulfilled more consistently than others. Nearly 1 in six countries fully meets its obligations with regard to at least one of four rights, the right to housing, work, food, and education. Although no country fully meets its obligation to provide its citizens and residents with the highest level of health attainable, some nearly do so (maximum ESRF-1 and ESRF-2 right to health scores are 99.95\% and $96.99 \%$, respectively). 


\section{Findings: Policy implications}

\section{Incomes and Resources: Closing the Progressive Realization 'Escape Hatch'}

Figure 8 plots the relationship between per capita GDP and performance on the ESRF Index. The top left panel of figure 8 examines the relationship for our core index. Differences in per capita income levels explain just $5 \%$ of the variation in ESRF-1 values. Even if one eliminates countries that appear to be outliers (top right panel), the R-square value (at .2523) remains low. The results underscore the fact that the effort of a substantial number of these countries is inadequate, even considering their low level of resources. Their obligations for progressive realization are not being acted upon adequately. Of the 44 countries scoring below $70 \%$ of obligations met, only 27 are low income countries. The accountability for this low performance rests primarily with the state in question. However, the role of the international community is also an important factor to be considered. Is the donor community providing assistance that is adequate not only in quantity but in quality? Many low income countries with low scores are countries that rely heavily on external cooperation resources which typically finance nearly the totality of the capital investment budget with domestic resources financing only the recurrent expenditures for personnel.

\section{[FIGURE 8 ABOUT HERE]}

The bottom left panel of figure 8 examines the relationship for high income OECD countries. As both the visual display and the extremely low R-square value reveal, poor performance on the ESRF-2 Index is not linked to per capita income level. Even if one reestimates the relationship after deleting two possible outliers (bottom right panel), the adjusted R-square remains extremely low. The low scores for the lowest ranked high income 
OECD countries highlight the need for more proactive action by the states concerned; economic growth will not resolve these countries' failure to meet their economic and social rights obligations.

\section{Economic and Social Policies}

The ESRF Index results highlight the need to examine a country's overall economic and social policies, rather than just legislative reforms, as necessary measures for the fulfillment of human rights. Economic and social rights obligations cannot be met in the absence of appropriate and effective economic and social policies. While low ESRF scores may be due to lack of legislative measures, such as a constitutional commitment to universal primary education, the implementation of such commitments depends on a wide range of national economic and social policies. These range from budget allocations and sectoral programs to broader policies such as trade and tariff policies that have an impact on employment and incomes. For example, management of patents under the trade agreements relating to intellectual property has important consequences for people who need to access life-saving medicines. Therefore policies regarding trade and intellectual property rights can play a role in helping or hindering the realization of the right to health.

The ESRF Index focuses attention on the state obligations to fulfill human rights, in contrast to much of human rights assessment practice that has focused on obligations to respect. ESRF scores less than $100 \%$ reflect shortfalls in fulfillment relative to obligations. Such shortfalls do not only reflect a failure to respect a human right, such as through discriminatory treatment of population groups and individuals. They reflect deficits in economic and social policies of a country to achieve universal fulfillment of a right. For example, low scores on the 
index could be due to: inadequate public spending; ineffective public policies and programs; historic neglect; and/or external constraints. These failings reflect either a lack of will to give the necessary priority to economic and social rights, ineffective policy choices, or both. While policy choices are primarily a national responsibility, in aid dependent low income countries, donors are also important stakeholders in formulating policy, since they provide much of the financing, and consensus on policy choices as part of the financing agreement. Thus, if economic and social rights obligations are to be met in aid dependent low income countries, donors must give the necessary priority to financing policies that effect their realization.

\section{Methodological Implications}

\section{ESRF Index as a Human Rights Measurement Tool}

ESRF Index scores differ from other measures of human progress and highlight the distinctiveness of the human rights approach to development. As can be readily seen from figure 8, they differ from GDP per capita which is the conventional measure of progress on which much of economic and social policy formulation relies. They also differ from human outcome measures in health, education, nutrition, housing, and work, and the composite measure of human development, the HDI. As can be seen from the bottom panel of figure 9 , there is no general relationship between the ESRF2 and the HDI. ${ }^{5}$ The ESRF index provides different information than the more conventional human outcome measures.

\section{[FIGURE 9 ABOUT HERE]}

Economic and social rights assessments of countries currently use indicators such as child mortality and school completion as outcome indicators ${ }^{6}$ to assess the extent to which 
countries are meeting specific economic and social rights obligations and the HDI as a summary index of the extent to which countries are meeting their overall obligation. However, the ESRF Index is a more appropriate measure for monitoring purposes and assessment of the effort made by the state to progressively realize economic and social rights to the maximum of their available resources. Countries with very similar HDI scores rank very differently on the ESRF Index. Table 7 shows pairs of countries with approximately equal HDI values, yet the ESRF scores and ranks differ widely between the country pairs. The contrast in ESRF scores occurs regardless of whether the country pairs have high, medium or low HDI scores. For example, both Benin and The Gambia have similarly low human development scores, yet The Gambia ranks $38^{\text {th }}$ among the 101 ESRF1 countries, while Benin ranks $72^{\text {nd }}$. Jordan and Turkey are medium human development countries, yet Jordan is among the top ESRF1 performing countries with a rank of $6^{\text {th }}$, while Turkey ranks $87^{\text {th }}$. The sharpest contrast among the ESRF1 countries is observed for Equatorial Guinea and Moldova. Their HDI scores are .717 and .719, respectively, yet Moldova fulfills over $95 \%$ of its ESR obligations ranking $4^{\text {th }}$ among ESRF1 countries, while Equatorial Guinea fails to meet even $16 \%$ of its obligations and ranks dead last $\left(101^{\text {st }}\right.$ place). The contrast extends to the high income OECD countries and is sharpest between Finland and the United States. Their respective HDI scores are roughly the same (.954 versus .950) yet Finland receives the best score on the ESRF2 Index (94.66\%) while the United States receives the worst score (76.97\%).

[TABLE 7 ABOUT HERE] 


\section{Country Assessments}

At the basic level, the ESRF scores help assess the performance of the state in meeting its obligations for progressive realization, and comparison with other countries should provide inspiration for good practice. The ESRF Index and its component rights scores can help pinpoint the areas where the greatest additional efforts by the state are required. Countries may score particularly poorly in some rights dimensions, but score higher on others. For example, Senegal's score on the right to education component of the ESRF Index is 30, while its score on the right to food component is just shy of $100 \%$. Senegal is seriously deficient with regard to meeting its obligations on the right to education and needs to focus efforts on determining the extent to which inadequate budgetary allocations and misguided policies account for the shortfall and accordingly take corrective action.

\section{Complementarity with Other Indicators}

Country assessments should use the ESRF Index together with other relevant information. The ESRF Index focuses on fulfillment rather than on violations, and on quantified human outcomes rather than on processes. It does not capture discrimination, participation, and transparency, all essential aspects of human rights obligations. These aspects have not been integrated into this index because they are difficult to quantify. They are important but better captured in other measurement frameworks being developed and proposed through other initiatives that include 'process' indicators such as participation, and 'structural' indicators such as constitutional guarantees, in addition to human outcome data. These other initiatives are led by: the Office of the High Commissioner for Human Rights for use by Treaty Bodies for monitoring state compliance, the University of Mannheim/FIAN project on the right to food 
(Riedel, 2006; FIAN International 2009); the former Special Rapporteur for the Right to Health, Paul Hunt, and colleagues for the Right to Health (Office of the High Commission on Human Rights, 2008); and the NGO Centre on Housing Rights and Evictions (COHRE) for the right to adequate housing (Roaf, Khalfan, and Langford, 2005).

The complementarity of the ESRF Index to other measures is summarized in table 8. This complementarity can be illustrated by considering a particular case. For example, Jordan ranks sixth out of 101 countries in the ESRF1 rankings. From an aggregate perspective Jordan is performing very well in fulfilling the rights of its citizens to education, health, food, adequate housing, and decent work. This can be attributed to good practices in economic and social policy that have emphasized allocation of public funds to the social sectors. However, the country also faces serious lags in its obligations with respect to non-discrimination, particularly in terms of women's enjoyment of equal educational opportunities, as well as refugees' access to decent housing. Disaggregated data on income distribution, education, health, sanitation, poverty, and employment show significant disparities between women and men, rural and urban populations, and refugees and non-refugees. The numbers suggest ongoing discrimination against women and refugees in policy efforts to fulfill economic and social rights. At the same time however, Education Law (3), adopted in 1994, bars gender discrimination in education. The outcome data on education rights enjoyment therefore contrasts sharply with that on education related structural and institutional guarantees. Moreover, despite strong performances in terms of aggregate outcome measures in the area of the right to health, Jordan's Constitution does not recognize a right to health, and the national health plan does not include an explicit commitment to universal access to health services, so Jordan performs 
poorly on economic and social rights measures that focus on institutional guarantees (Backman 2008). The ESRF Index also supplements other sources of information in monitoring state compliance with economic, social, and cultural rights obligations. For example, the most recent concluding observations on Jordan by the Committee on Economic, Social, and Cultural Rights, CESCR, focuses largely on issues of legislative action, starting with the publication of the International Covenant on Economic, Social Cultural Rights in the Official Gazette and its incorporation in national legislation. The CESCR's concerns focus on issues of violation - such as the trade union rights and marital rape - and its recommendations are largely concerned with institutional strengthening. Concern is briefly expressed regarding poverty and unemployment in the country, as well as issues of equity. The ESRF Index adds to such reporting by providing a sharper assessment of the extent to which different economic and social rights outcome obligations are being met.

\section{[TABLE 8 ABOUT HERE]}

\section{Disaggregated ESRF Index}

The ESRF Index does not build in inequality and discrimination. However, it can identify problems of disparities within a country when it is disaggregated for different population groups within a country. Disaggregated ESRF indices were estimated for two countries: Brazil and the United States (Guyer, Fukuda-Parr, Randolph and Daniels, 2009; Randolph and Prairie, 2009).

The US falls short of meeting its economic and social rights obligations, ranking 24th (worst) out of the 24 high income OECD countries for which the ESRF2 scores could be computed. Relative to other high income countries, its score is worst or nearly worst along 
each right. But in addition, there are significant differences among the 50 states and across racial groups. While no state is fully meeting its economic and social rights obligations, most states come closest to fulfilling the right to education. Most states are most deficient in fulfilling the right to food. There are substantial differences in the extent to which the right to health is met across ethnic groups within any state. The marginalized ethnic group differs across states, but is generally non-Hispanic blacks.

Although Brazil as a country performs relatively well in the global ESRF Index rankings, placing $14^{\text {th }}$ out of 101 countries, the results of the disaggregated state level ESRF Index values and rankings show that this is an average that obscures a wide range of performance. Moreover, performance does not depend solely on resources nor on the level of human development. Our findings highlight the strong performance in fulfilling economic and human rights obligations on the part of relatively poorer states such as Paraná and the poor performance of higher income states, notably the Distrito Federal (Federal District) ${ }^{7}$, which was the richest state overall in GDP per capita terms and ranked $1^{\text {st }}$ among all states in terms of the HDI in 2005 yet ranked $10^{\text {th }}$ out of 27 states on our index. The state level ESRF Index rankings also differ significantly from rankings based on the disaggregated Human Development Index which has recently been used to measure human development in Brazil at the national, state and even municipal level. ${ }^{8}$ The Brazil ESFR Index shows that no state is fully meeting its obligations for progressive realization, and that the lags are more marked in areas of decent work and housing than in areas of food, health and education. 


\section{Conclusions}

Quantitative indicators are an essential tool for assessing the performance of States in fulfilling their obligations to enable their citizens and residents to adequately realize economic and social rights. The practice of monitoring - through state reporting to UN treaty bodies, and through reviews by national human rights institutions, and through civil society advocacy - is an increasingly vibrant field of activity. Actors engaged in this process are in search of new tools for rigorous assessment. The ESRF estimates for the composite index and component rights provide a useful tool to this end. The ESRF Index provides information that complements other sources of information in a variety of ways.

First, it differs from development indicators including GDP per capita, socio-economic outcome indicators such as mortality rates, and the composite HDI, because it measures outcomes against the obligations of progressive realization to the maximum of available resources. It is therefore a stronger measure of state response and a more appropriate measure for state accountability than the simple socio-economic outcome measures.

Second, it is complementary to many of the new human rights indicators being developed and proposed by the United Nations ${ }^{9}$, civil society $^{10}$ and academia ${ }^{11}$ because these indicators focus on structural and process aspects of human rights obligations as opposed to the progressive realization and fulfillment aspects, or on violations and negative obligations rather than positive obligations. In particular, the ESRF Index supplements other qualitative indicators; complex frameworks with dozens of indicators; process and structural indicators on questions such as discrimination and participation; and standard reporting approaches which focus on institutional and legal rather than socio-economic outcome measures. A single 
number for all economic and social rights combined focuses attention on economic and social rights fulfillment as a normative policy objective, and helps policy makers and civil society identify priorities.

An important question in developing indicators and measurement tools is the level of aggregation. In different contexts and for different uses, different levels of aggregation - or detail - are required. Detailed indicators are necessary in analyzing specific cases of human rights violation and in formulating national policy on specific issues, such as schooling for street children. However, to reveal overall neglect of economic and social rights obligations in a country, a summary measure of economic and social rights is needed.

As indicated in our concept and methodology paper, human rights measurement is an emerging field in need of further research. Our earlier paper highlighted the frontier challenges in research and data collection to strengthen measurement methods. The findings from the ESRF estimates highlight the frontier challenges in using the ESRF Index for research on the process of human rights fulfillment, especially the role of different economic and social development policies. In particular, further analysis of ESRF Index results should be pursued to reveal the policy explanations for poor and high performance. For example, a central issue is the role played by budgetary resources and processes, including levels and allocations expenditure allocations, the role of participatory budgeting, and governance factors such as corruption. The ESRF Index is not to be taken as a fixed tool or methodology. The broad approach provides a coherent framework for evaluating economic and social rights fulfillment, but should be continually revised and refined as it becomes applied in assessing the state of 
human rights fulfillment, and used to hold states to account for national and international

policies in promoting economic and social rights fulfillment.

\section{References:}

BACKMAN, Gunilla, Paul HUNT, Rajat KHOLSA, Camila JARAMILLO-STRAUSS, Belachew Mekuria FIKRE, Caroline RUMBLE, David PEVALIN, David Acurio PÁEZ, Mónica Armijos PINEDA, Ariel FRISANCHO, Duniska TARCO, Mitra MOTLAGH, Dana FARCASANU, Cristian VLADESCU. (2008) 'Health systems and the right to health: an assessment of 194 countries'. Lancet, 372, pp. 204785.

FIAN International. (2009) For the Right to Food | FIAN, viewed September 14, 2009, < http://www.fian.org >.

FUKUDA-PARR, Sakiko, Terra LAWSON-REMER, and Susan RANDOLPH. (2009) 'An Index of Economic and Social Rights Fulfillment: Concept and Methodology', Journal of Human Rights, 8, pp. 1-27.

GUYER, Patrick, Sakiko FUKUDA-PARR, Susan RANDOLPH, and Louise DANIELS. (2009) 'Measuring the Progressive Realization of Economic and Social Human Rights in Brazil: A Disaggregated Economic and Social Rights Fulfillment Index'. Working paper dated August 10, 2009.

INTERNATIONAL LABOUR ORGANIZATION. (2009) Key Indicators of the Labour Market Online, viewed July 13, 2009, < http://www.ilo.org/kilm >.

LUXEMBOURG INCOME STUDY. (2009) LIS Key Figures Online, viewed July 13, 2009, < http://www.lisproject.org/key-figures/key-figures.htm >.

OFFICE OF THE HIGH COMMISSION ON HUMAN RIGHTS. (2008) Report on Indicators for Promoting and Monitoring the Implementation of Human Rights' International Human Rights Instrument. $\left(20^{\text {th }}\right.$ Meeting of chairpersons of the human rights treaty bodies, Geneva, June 2627), UN Doc. HRI/MC/2008/3, viewed July 20, 2009, < http://www.ohchr.org/English/bodies/icm-me/docs/HRI.MC.2008.3EN.pdf >.

ORGANIZATION FOR ECONOMIC COOPERATION AND DEVELOPMENT, OECD. (2009) International Program for Student Assessment (PISA) Online, viewed July 13, 2009, < http//www.pisa.oecd.org >.

RANDOLPH, Susan and Michelle PRAIRIE. (2009) 'Economic Rights in the Land of Plenty', Paper presented at the Economic Rights Workshop, April,18, 2009, University of Connecticut. 
RIEDEL, Eibe. (2006) The IBSA Procedure as a Tool of Human Rights Monitoring, viewed September 17, 2009, <http://ibsa.uni-mannheim.de/2 - The IBSA-

Procedure as a Tool of Human Rights Monitoring 1 .pdf>

ROAF, Virginia, Ashfaq KHALFAN and Malcolm LANGFORD. (2005) “Monitoring Implementation of the right to Water: A Framework for Developing Indicators" Global Issues Papers, No. 14, viewed September 17, 2009,

<http://www.canadians.org/water/documents/righttowaterindicators.pdf>,.

UNITED NATIONS. (1966a) International Covenant on Economic, Social and Cultural Rights (ICESCR), adopted 16 Dec. 1966, G.A. Res. 2200 (XXI), U.N. GAOR, $21^{\text {st }}$ Sess., Supp. No. 16, U.N. Doc. A/6316 (1966), 993 U.N.T.S. 3 (entered into force 3 Jan. 1976).

UNITED NATIONS DEVELOPMENT PROGRAMME BRAZIL. Atlas do Desenvolvimento Humano no Brasil, viewed September 11, 2009, < http://www.pnud.org.br/atlas/>.

UNITED NATIONS STATISTICS DIVISION, DEPARTMENT OF ECONOMIC AND SOCIAL AFFAIRS. (2009) Millennium Development Goals Indicators Online, viewed June 11-July11, 2009,< http://mdgs.un.org/unsd/mdg/Data.aspx >.

UPPSALA CONFLICT DATA PROGRAM AND THE INTERNATIONAL PEACE RESEARCH INSTITUTE, OSLO. (2007) UCDP/PRIO Armed Conflict Dataset Codebook: Version 4-2009, viewed 22 January 2009, < http://www.prio.no/CSCW/Datasets/Armed-Conflict/UCDP-PRIO/ >.

WORLD BANK. (2009) PovCalNet Online, viewed June 11-July11, 2009, < http://iresearch.worldbank.org/PovcalNet/jsp/index.jsp >.

WORLD BANK GROUP. (2009a) EdStats Online, viewed June 11 - July 11, 2009, < http://www.worldbank.org/education/edstats $>$.

WORLD BANK GROUP. (2009b) HNPStats Online, viewed June 11-July 11, 2009, < http://web.worldbank.org/WBSITE/EXTERNAL/TOPICS/EXTHEALTHNUTRITIONANDPOPULATION /EXTDATASTATISTICSHNP/EXTHNPSTATS/0,,menuPK:3237172 pagePK:64168427 piPK:641684 35 theSitePK:3237118,00.html >.

WORLD BANK GROUP. (2009c) World Development Indicators Online, viewed June 11-July 11, 2009, < http://ddp-ext.worldbank.org.ezproxy.lib.uconn.edu >.

WORLD HEALTH ORGANIZATION. (2009a) WHO Global InfoBase Online. viewed June 11-July 11, 2009, < www.who.int/research/en/ >.

WORLD HEALTH ORGANIZATION. (2009b)WHO Statistical Information System (WHOSIS) Online, viewed June 11-July11, 2009, < www.who.int/whosis/ >. 
${ }^{1}$ We refer readers to our previous paper (Fukuda-Parr, et al. 2009) for a full discussion of the criteria guiding indicator selection, as well as the strengths and weaknesses of the selected indicators.

${ }^{2}$ To guard against the use of unreliable data, observations from countries enduring major conflicts within the past ten years were excluded from the frontier plots. Countries enduring major conflicts were identified using the Uppsala Conflict Data Program (2007). In addition, because transitional countries' per capita GDP plummeted during the 1990s yet their human capital and the physical infrastructure laid prior to the transition supporting ESR fulfillment did not deteriorate to the same degree, to ensure the AFPs reflect what is reasonably achievable by any country, transitional countries were assigned their pre-transitional per capita GDP until their per capita GDP levels rebounded. See Fukuda-Parr et al. 2009 for further details.

${ }^{3}$ Scatter plots of the percentage of babies that are above 2500 grams (that are "normal" birth weight) against per capita income indicate the percentage of normal birth weight babies initially rises with per capita income but subsequently falls with further gains in per capita GDP. The initial rise is likely due to improved nutrition and health care as per capita income rises from low to middle income levels. The subsequent decline is likely due to medical technology enabling premature infants that otherwise would be stillbirths to survive. Because we only use this indicator for high income countries, we set the frontier at the highest value achieved by a high income country as opposed to the highest value achieved by any country.

${ }^{4}$ The primary data sources are the World Development Indicators Online (The World Bank Group, 2009c); EdStats Online (The World Bank Group, 2009a), HNPStats Online (The World Bank Group, 2009b); PovCalNet Online (World Bank, 2009); Key Indicators of the Labor Market (KILM) Online (International Labour Office, 2009), WHO Statistical Information System (WHOSIS) Online (World Health Organization, 2009b), WHO Global Infobase Online (World Health Organization, 2009a), International Programme for Student Assessment (PISA) Online (Organization for Economic Cooperation and Development, 2009), LIS Key Figures Online (Luxembourg Income Study, 2009), and Millennium Development Goals Indicators Online (United Nations Statistics Division, 2009).

${ }^{5}$ Although among non-OECD high income countries a positive correlation exists (top panel of figure 9), the relationship is quite weak.

${ }^{6}$ See, for example, the indicators proposed by the Office of the High Commission on Human Rights, OHCHR, for use in state monitoring in United Nations human rights processes for economic and social rights, or the indicators proposed by Backman et al. (2008) to monitor the right to health.

${ }^{7}$ Brazil has 26 states and one "autonomous sub-national entity", the Distrito Federal, which includes the capital Brasília and its outskirts. However, Brazilian record-keeping accords the Distrito Federal the same status as a state.

${ }^{8}$ See for example the Atlas do Desenvolvimento Humano no Brasil ('Brazilian Atlas of Human Development') developed by UNDP Brazil.

${ }^{9}$ See for example, the Office of the High Commission on Human Rights, OHCHR, "Report on Indicators for Promoting and Monitoring the Implementation of Human Rights' International Human Rights Instrument"” (2008).

${ }^{10}$ See for example, Roaf, Khalfan and Langford (2005) for an example of the work being done by the Center on Housing Rights and Evictions, COHRE, and Riedel (2006) for the work being done by FIAN International and the University of Mannheim.

${ }^{11}$ See Backman et al. 2008 for the right to health. 
Figure 1: Frontier Plots for Developing Countries Only

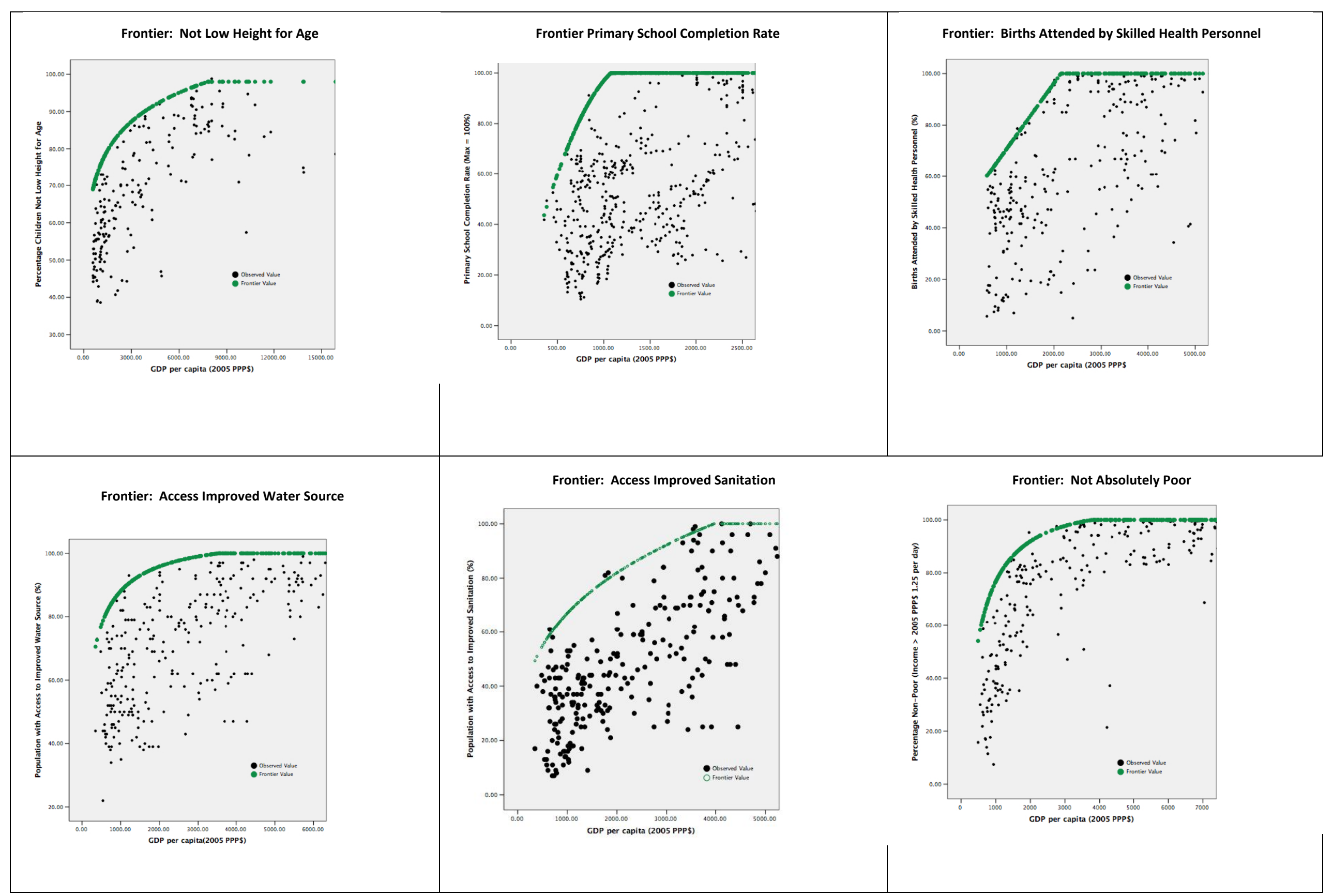


Figure 2: Frontier Plots for Both Developing and High Income Countries

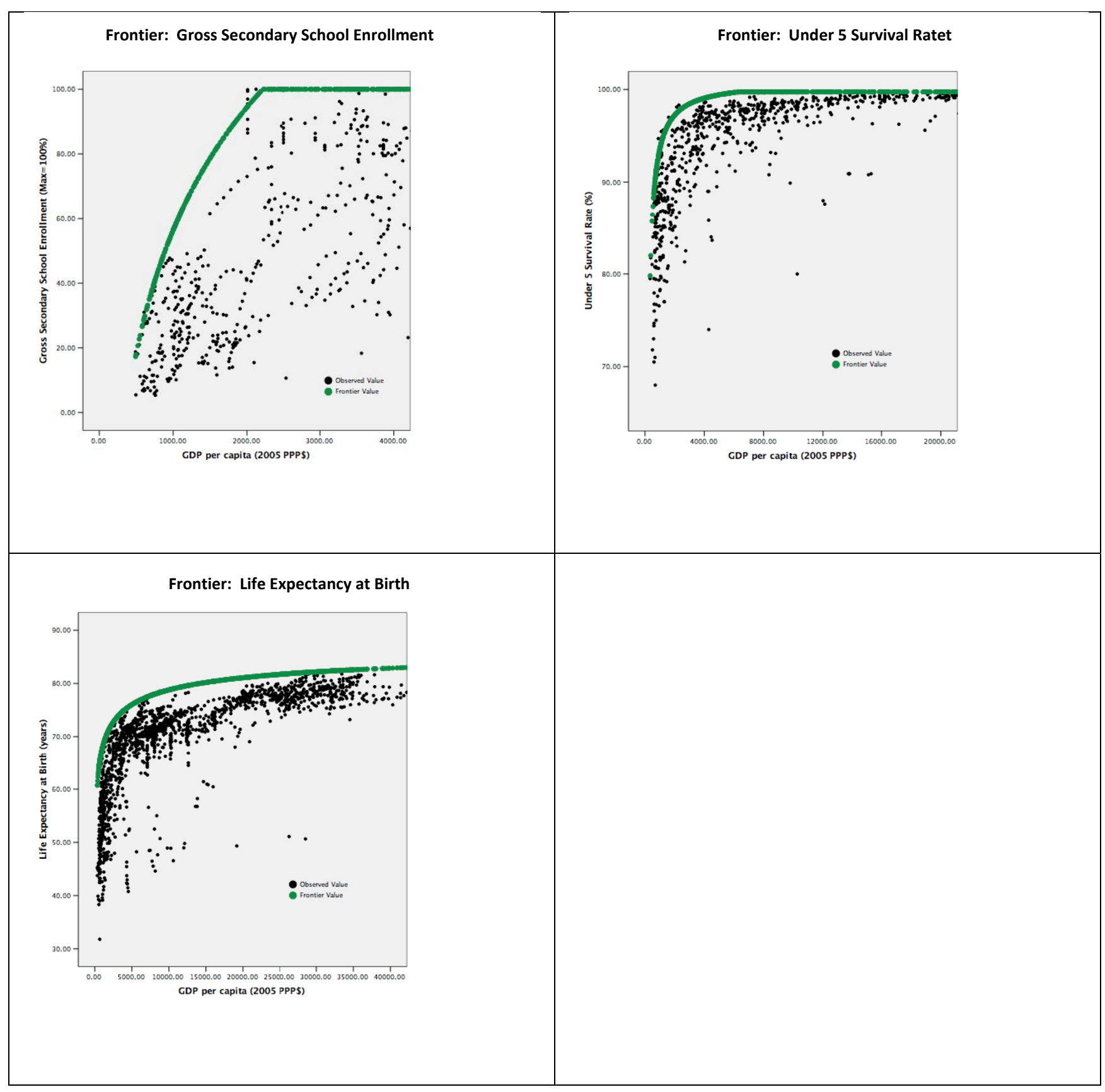


Figure 3: Frontier Plots for High Income Countries

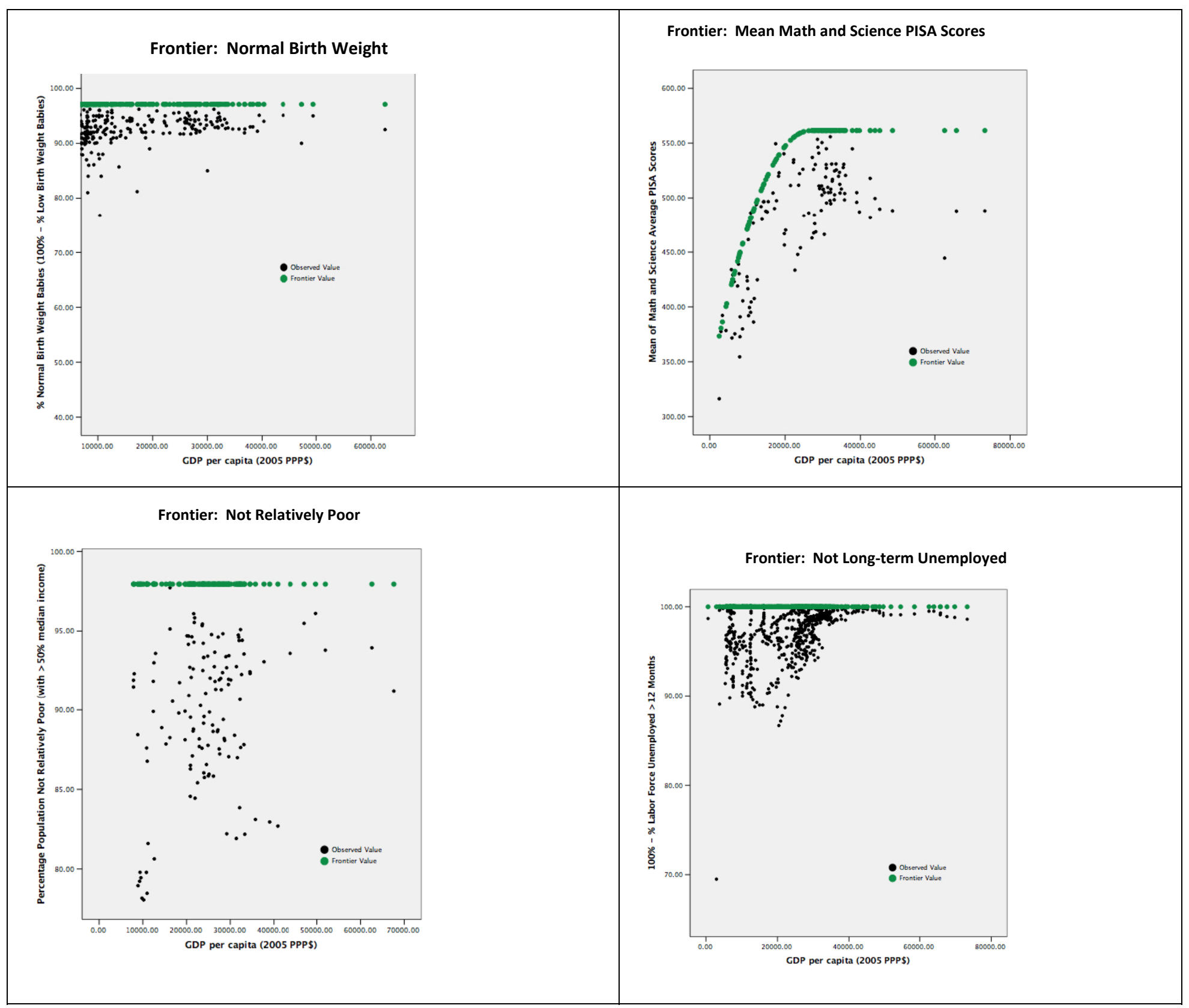




\section{Figure 4}

Rescaling Indicator Values

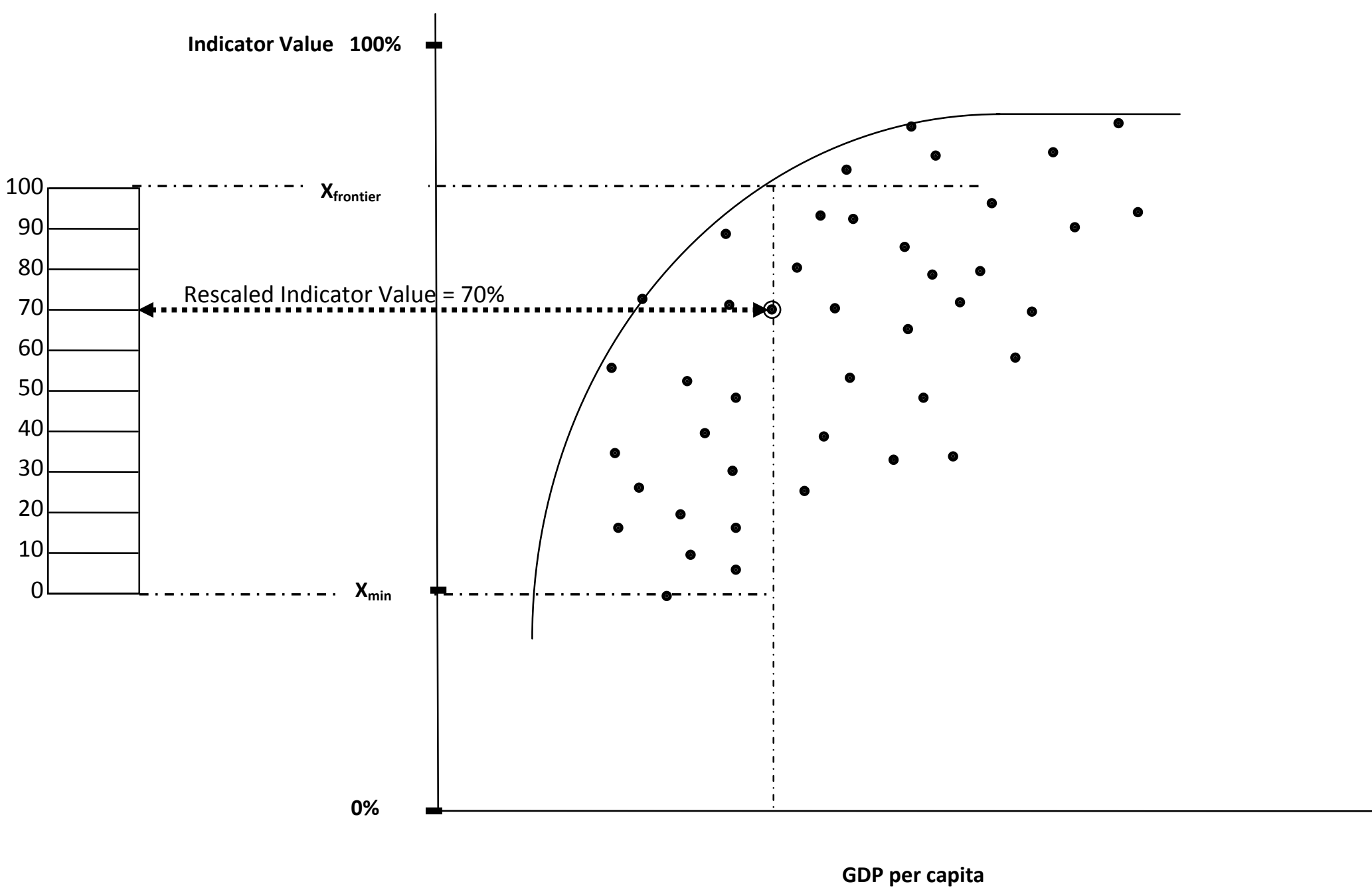


Figure 5

Formula $F: \beta=1.0$ verses $\beta=0.5$

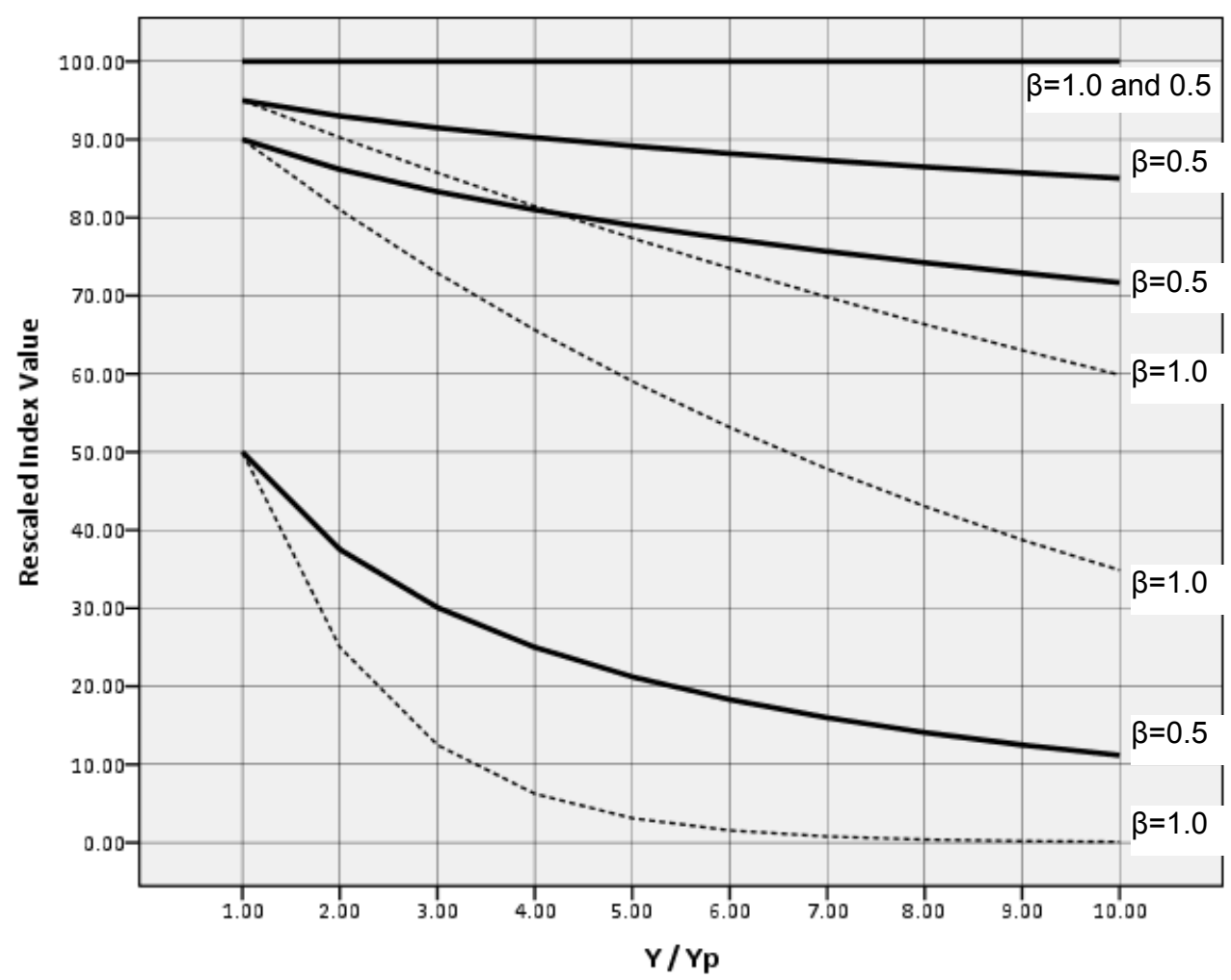




\section{Figure 6}

ESRF-1: Core Economic \& Social Rights Fulfillment Index

RIGHT

INDICATOR

INDICATOR

INDEX

RIGHT

INDEX

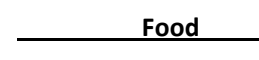

NS: \% Children (0-5)

Stunted
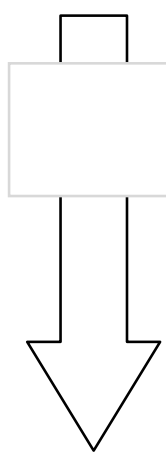

Right to Food

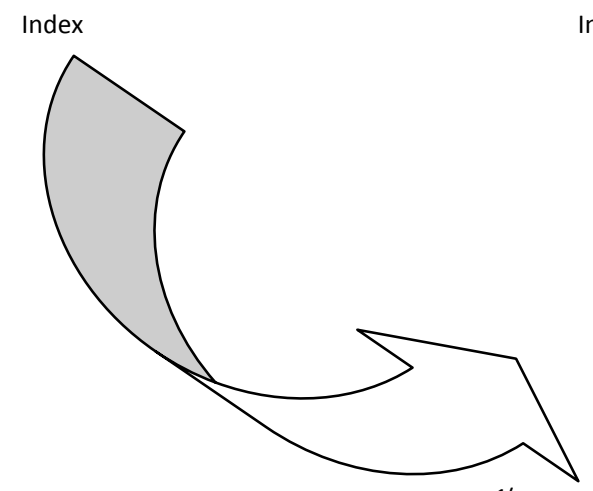

Housing

Work

LE: Life U5S: \% Under 5 AB: \% Assisted

Education

GSER: Gross Secondary IS: \% Improved IW: \% Improved

NP: \% Above \$1.25

PCR: Primary

Enrollment Rate

Sanitation

Water

(2005 PPP\$) Poverty Line
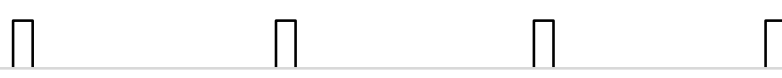

$\Pi$

Step 1: Index $=100 *($ Indicator Value - Minimum Value $) /($ Frontier Value - Minimum Value $)$

Step 2: Adiust Index for countries with $Y>Y p-A d j u s t e d$ Index $=100\left[(\right.$ Index $/ 100)$ raised to $(Y / Y p)^{\beta} 1$

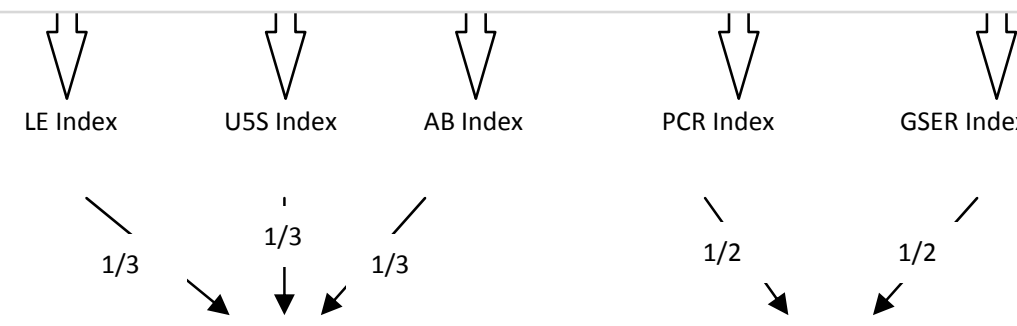

Right to Health

Right to Education

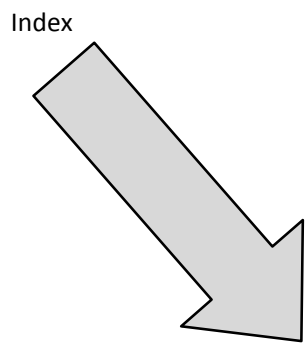

Core Economic \& Social Rights Fulfillment Index
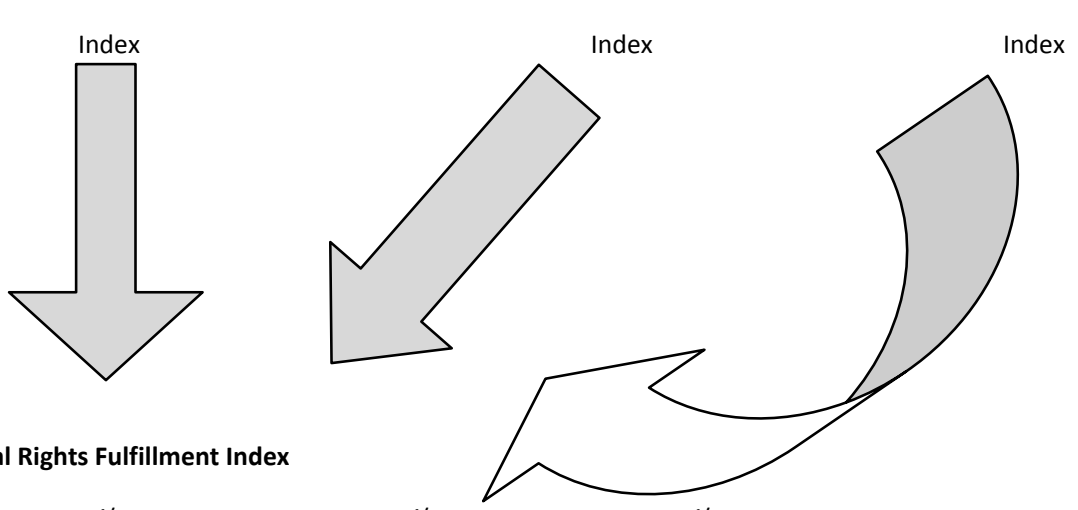

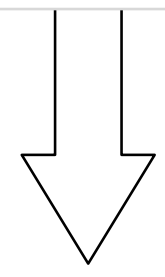

Right to Work
IW Index

$\backslash$

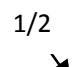

4

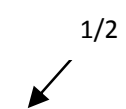

Right to Housing

dex 


\section{Figure 7}

\section{ESRF-2: Economic \& Social Rights Fulfillment Index for High Income OECD Countries}

RIGHT

INDICATOR

INDICATOR

INDEX

RIGHT

INDEX

\begin{abstract}
Food
NBW: \% Normal (not low)
\end{abstract}

Birth Weight

$\longrightarrow$

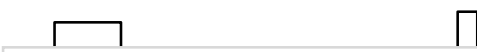

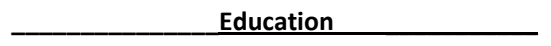

GSER: Gross Secondary PISA: Average of Math

Enrollment Rate \& Science PISA Score
Work

NRP: \% Not Relatively Poor NLTU: \% Not Long-term

( $>50 \%$ median income)

Unemployed

$\Pi \prod \Pi \Pi \Pi$ П

Step 1: Index $=100 *($ Indicator Value - Minimum Value $)$ / (Frontier Value - Minimum Value $)$

Step 2: Adiust Index for countries with $Y>Y p-$ Adiusted Index $=100 \Gamma\left(\right.$ Index/100) raised to $(Y / Y p)^{\beta} 1$
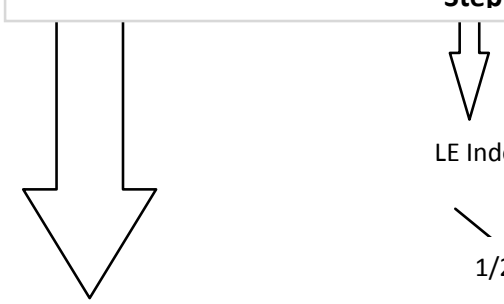

LE Index

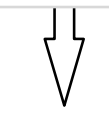

U5 Index

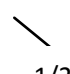

$1 / 2$

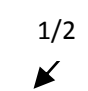

Right to Health

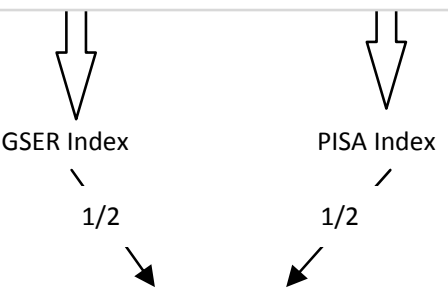

Right to Education

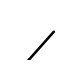

Right to Food

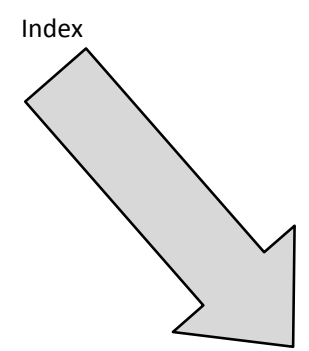

Economic \& Social Rights Fulfillment Index for High Income OECD Countries
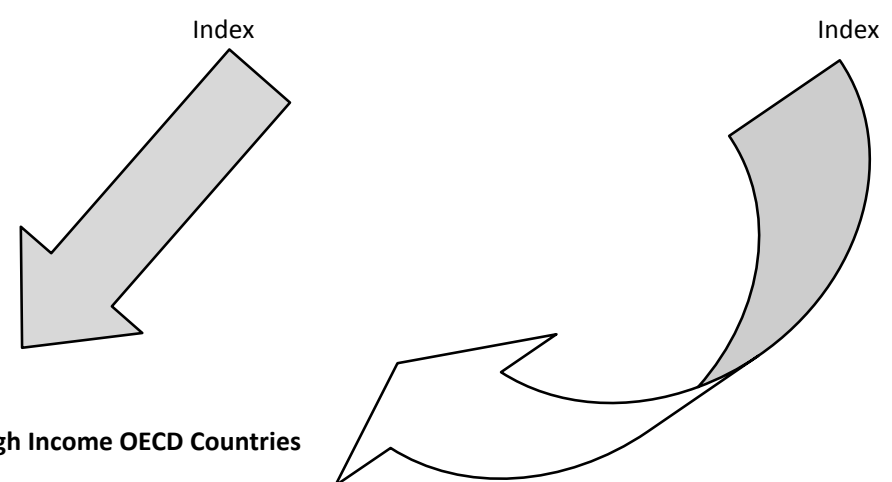

Step 3: $\left[\left(\text { Right to Food Index }{ }^{1 / \alpha}+\text { Right to Health Index }{ }^{1 / \alpha}+\text { Right to Education Index }^{1 / \alpha}+\text { Right to Work Index }^{1 / \alpha}\right) / 4\right]^{\alpha}$ 
Figure 8: Economic and Social Rights Fulfillment Index and Per capita GDP

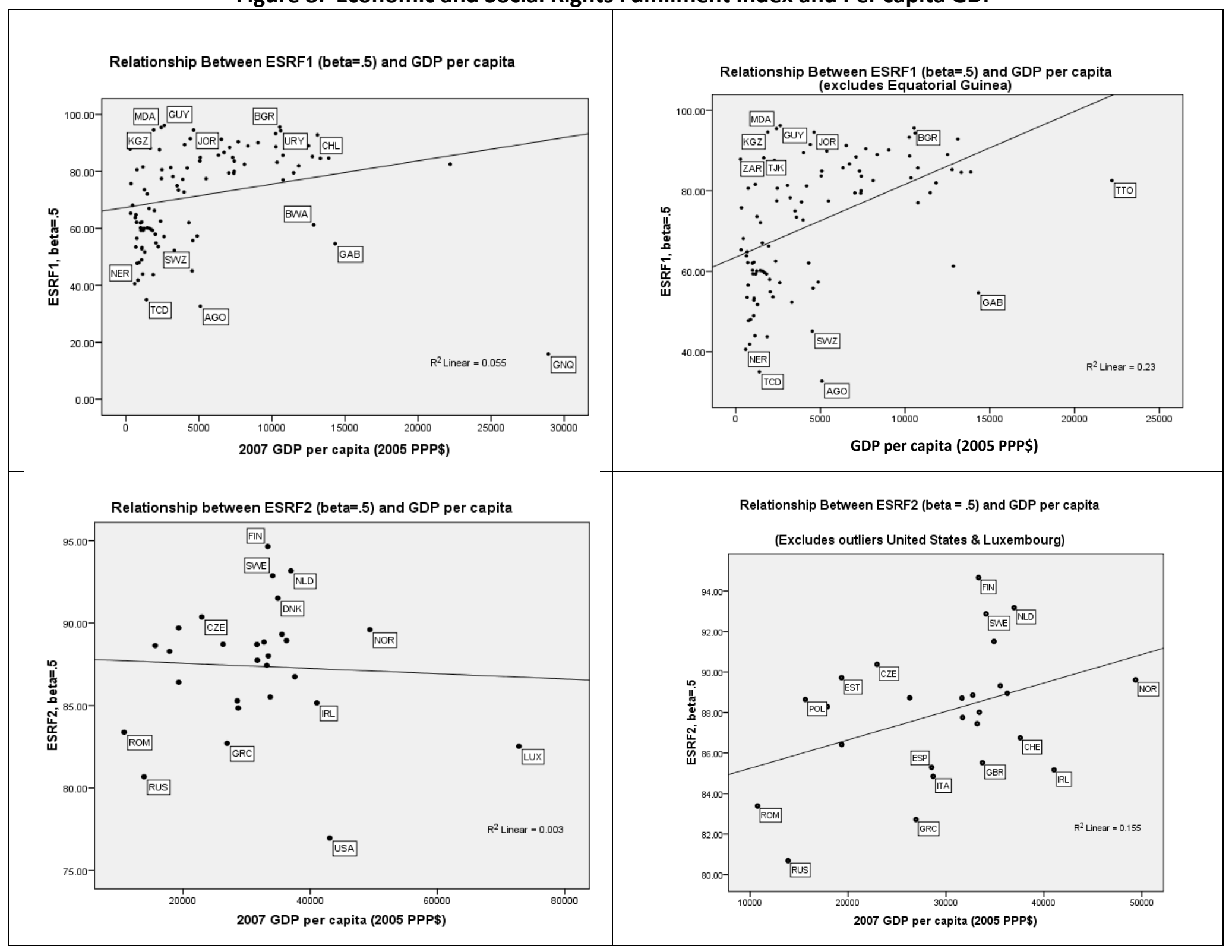


Figure 9: Economic and Social Rights Fulfillment Index and the Human Development Index

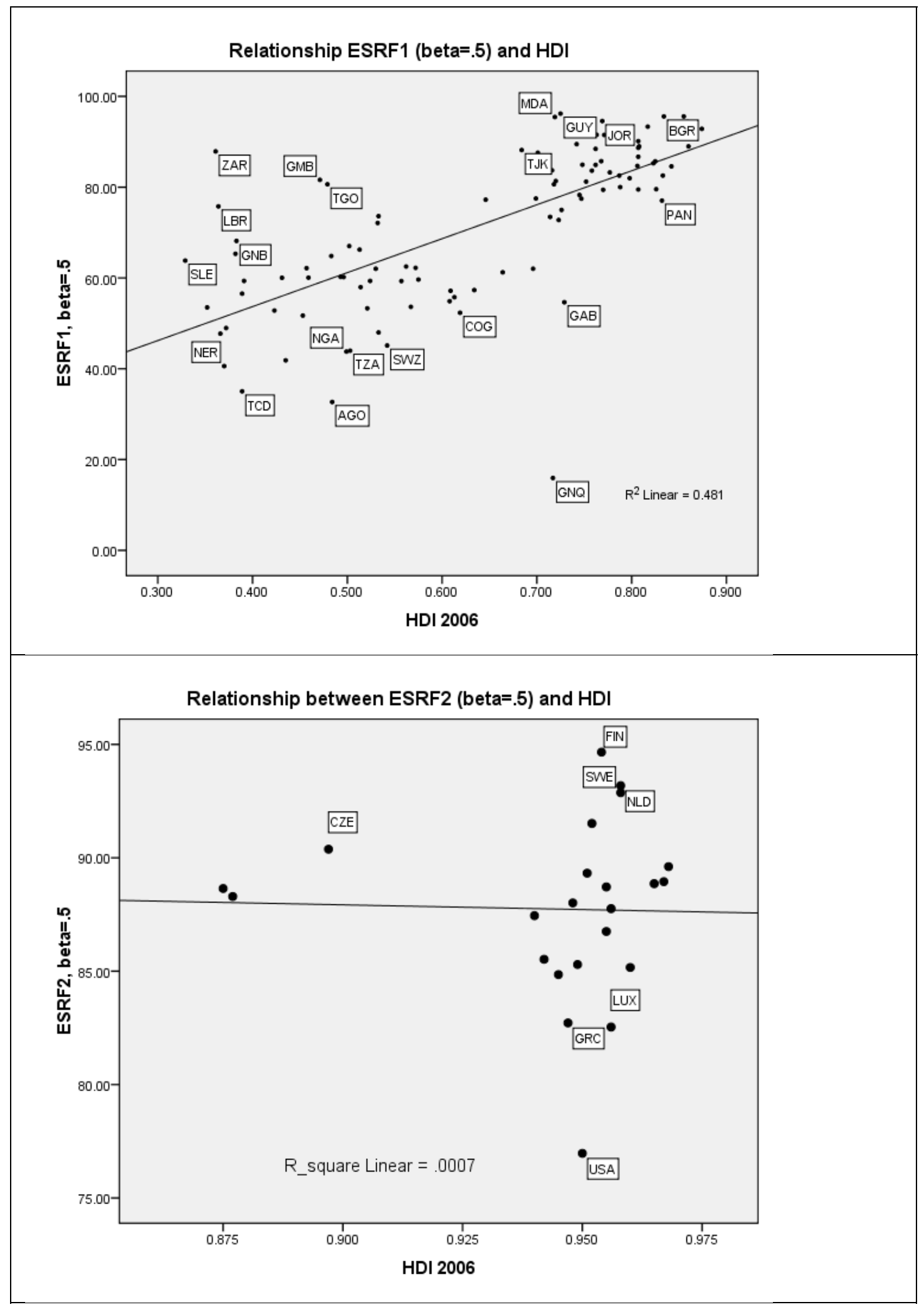


Table 1: Observations Defining Frontiers \& Indicator Minimums

\begin{tabular}{|c|c|c|c|}
\hline Right & Indicator & Country/Year Observations Defining Frontier & $\begin{array}{l}\text { Minimum Value of Indicator } \\
\text { Observed (rounded down) }\end{array}$ \\
\hline \multicolumn{4}{|c|}{ Right to Food } \\
\hline Developing & $\%$ not stunted & $\begin{array}{l}\text { Togo 2006, The Gambia 2000, Senegal 2005, Jordan 1997, Dominican Republic } \\
\text { 2000, Macedonia, FYR } 2004 .\end{array}$ & $36 \%$ (Burundi 2000) \\
\hline High Income & $\%$ not low birth weight & Iceland 1992. & 40\% (Lao, PDR 1991, 1994) \\
\hline \multicolumn{4}{|c|}{ Right to Education } \\
\hline Developing & $\begin{array}{l}\text { Primary school completion rate } \\
(\mathrm{Max}=100 \%)\end{array}$ & $\begin{array}{l}\text { Congo, Dem. Rep. 1992, 1994, Burundi 1993, Malawi 2002, Myanmar 2005, } \\
\text { China } 1990 .\end{array}$ & 10\% (Mali 1990) \\
\hline All countries & $\begin{array}{l}\text { Gross secondary school enrollment rate } \\
(\mathrm{Max}=100 \%)\end{array}$ & $\begin{array}{l}\text { Ethiopia 2002, 2003, Malawi 2001, 2002, Togo 2004, 2005, Myanmar 2005, } \\
\text { Vietnam 1999, Uzbekistan 1991, 2001, 2005, 2006, Kyrgyz Rep. } 1991 .\end{array}$ & 5\% (Mozambique 1999) \\
\hline High Income & Average math \& science PISA score & $\begin{array}{l}\text { Indonesia } 2003 \text { 2006, Jordan 2006, Thailand 2000, Latvia 2000, 2003, Poland } \\
\text { 2003, Korea, Rep. 2000, 2003, Japan 2000, Finland } 2006 .\end{array}$ & 310 (Peru 2000)a \\
\hline \multicolumn{4}{|c|}{ Right to Health } \\
\hline Developing & $\%$ births assisted by skilled health workers & Malawi 2002, Benin 2005, 2006, Uzbekistan 1996, 2000, 2006, Djibouti 2006. & 5\% (Equatorial Guinea 1994) \\
\hline All Countries & $\%$ child survival rate & $\begin{array}{l}\text { Vietnam 1990, 1995, 2000, 2005, 2006, China 1990, Syrian Arab Republic 2005, } \\
\text { 2006, Ethiopia 2005, 2006, Burundi 1995, Thailand 2005, 2006, Croatia } 2006 .\end{array}$ & 68\% (Niger 1990) \\
\hline \multicolumn{4}{|c|}{ Right to Housing } \\
\hline Developing & $\%$ access improved water source & Burundi 1995, Nepal 2000, Comoros 1990, 1995, 2000, Tonga 1990. & 4\% (Afghanistan 1990, 1995) \\
\hline Developing & $\%$ access improved sanitation & $\begin{array}{l}\text { Malawi 2000, 2004, Djibouti 1995, 2000, 2004, Samoa 1990, 1995, 2000, } \\
\text { Jordan } 1990 .\end{array}$ & 3\% (Ethiopia 1990) \\
\hline \multicolumn{4}{|c|}{ Right to Work } \\
\hline Developing & \% income $>=\$ 1.25$ (2005 PPP) per day & $\begin{array}{l}\text { Ethiopia 2005, Kenya 1997, Kyrgyz Republic 1999, Djibouti 1996, Morocco } \\
\text { 1990, Albania 1996, Azerbaijan } 2005 .\end{array}$ & 7\% (Guinea 1991) \\
\hline High Income & $\%$ income $>=50 \%$ median income & Slovak Republic 1992. & 72\% (Peru 2004) \\
\hline High income & $\%$ labor force not long-term unemployed & Mexico 1998-2004, Korea, Rep. 2003-2007. & 69\% (Armenia 2001) \\
\hline
\end{tabular}

a. Actual value for Peru in 2000 was 312.5; this was rounded down to nearest 10 . 
Table 2: International Frontier Equations

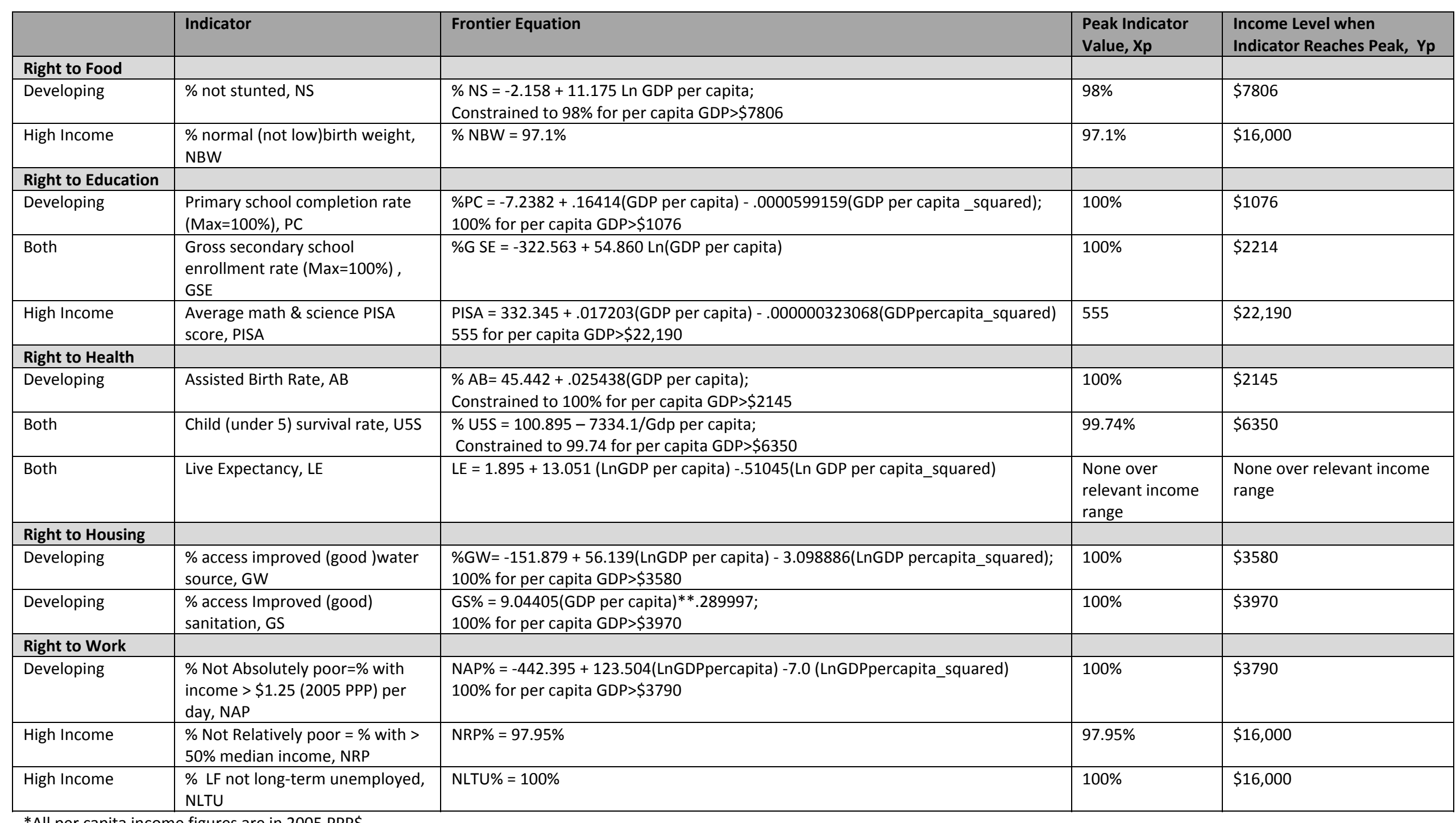

*All per capita income figures are in 2005 PPP\$ 
Table 3

\section{Descriptive Statistics}

Panel A: ESRF-1--All Observations with Data on One or More Rights

\begin{tabular}{|c|c|c|c|c|c|c|c|}
\hline & \multicolumn{7}{|c|}{ Panel A: ESRF-1--All Observations with Data on One or More Rights } \\
\hline & $\mathrm{N}$ & Minimum & Average & Maximum & Average & Mean & Std. Deviation \\
\hline & & & Lowest 5 & & Highest 5 & & \\
\hline Aggregate ESRF1 & 101 & 15.94 & 33.22 & 96.20 & 95.48 & 71.6895 & 17.26745 \\
\hline Right to Health & 150 & 31.87 & 40.09 & 99.95 & 98.43 & 82.5995 & 14.88494 \\
\hline Right to Housing & 149 & 12.18 & 26.95 & 100.00 & 100 & 74.5994 & 19.48185 \\
\hline Right to Decent Work & 112 & 5.71 & 20.17 & 100.00 & 100 & 77.3880 & 23.10983 \\
\hline Right to Food & 121 & 12.23 & 19.61 & 100.00 & 100 & 66.9158 & 22.23450 \\
\hline Right to Education & 149 & 5.79 & 14.02 & 100.00 & 100 & 71.3937 & 23.22789 \\
\hline Valid N (listwise) & 101 & & & & & & \\
\hline
\end{tabular}

Panel B: ESRF-1-Only Observations with Data on All Rights

$\mathrm{N}$ Minimum Average Maximum Average Mean Std. Deviation Lowest 5 Highest 5

\begin{tabular}{lrrrrrrr} 
Aggregate ESRF1 & 101 & 15.94 & 33.22 & 96.20 & 95.48 & 71.6895 & 17.26745 \\
Right to Health & 101 & 31.87 & 40.09 & 99.95 & 98.02 & 78.3899 & 15.64701 \\
Right to Housing & 101 & 12.18 & 26.95 & 100.00 & 97.46 & 70.9644 & 19.26111 \\
Right to Decent Work & 101 & 5.71 & 20.17 & 100.00 & 99.97 & 76.1588 & 23.51828 \\
Right to Food & 101 & 12.23 & 19.61 & 100.00 & 100 & 66.3014 & 22.87729 \\
Right to Education & 101 & 5.79 & 14.02 & 100.00 & 99.95 & 66.6331 & 24.07315 \\
Valid N (listwise) & 101 & & & & & & \\
\hline
\end{tabular}


Table 4

\section{Descriptive Statistics}

Panel A: ESRF2--All Observations with Data on One or More Rights

\begin{tabular}{|c|c|c|c|c|c|c|c|}
\hline & $\mathrm{N}$ & Minimum & $\begin{array}{l}\text { Average } \\
\text { Lowest } 5\end{array}$ & Maximum & $\begin{array}{l}\text { Average } \\
\text { Highest } 5\end{array}$ & Mean & Std. Deviation \\
\hline Aggregate ESRF-2 & 24 & 76.97 & 82.45 & 94.66 & 92.52 & 87.6846 & 3.80310 \\
\hline Right to Health & 28 & 92.26 & 93.73 & 99.68 & 98.86 & 96.8264 & 1.78845 \\
\hline Right to Food & 28 & 84.04 & 86.62 & 98.44 & 96.65 & 91.7213 & 3.42342 \\
\hline Right to Education & 28 & 67.89 & 74.65 & 100.00 & 95.18 & 86.1455 & 7.37515 \\
\hline Right to Decent Work & 24 & 60.79 & 65.38 & 89.19 & 90.24 & 76.9849 & 8.60015 \\
\hline Valid N (listwise) & 24 & & & & & & \\
\hline
\end{tabular}

Panel B: ESRF-2--Only Observations with Data on All Rights

\begin{tabular}{|c|c|c|c|c|c|c|c|}
\hline & $\mathrm{N}$ & Minimum & $\begin{array}{l}\text { Average } \\
\text { Lowest } 5\end{array}$ & Maximum & $\begin{array}{l}\text { Average } \\
\text { Highest } 5\end{array}$ & Mean & Std. Deviation \\
\hline Aggregate ESRF-2 & 24 & 76.97 & 82.45 & 94.66 & 92.52 & 87.6846 & 3.80310 \\
\hline Right to Health & 24 & 92.26 & 93.73 & 99.68 & 98.76 & 96.6865 & 1.87944 \\
\hline Right to Food & 24 & 84.04 & 86.62 & 96.83 & 95.16 & 91.1768 & 3.18099 \\
\hline Right to Education & 24 & 67.89 & 74.94 & 100.00 & 95.03 & 85.8905 & 7.60276 \\
\hline Right to Decent Work & 24 & 60.79 & 65.38 & 89.19 & 90.24 & 76.9849 & 8.60015 \\
\hline Valid N (listwise) & 24 & & & & & & \\
\hline
\end{tabular}


Table 5

ESRF-1 Index and Component Right Indices

\begin{tabular}{|c|c|c|c|c|c|c|c|c|c|}
\hline & Country & $\begin{array}{c}2007 \\
\text { GDP per } \\
\text { capita } \\
\text { (2005 } \\
\text { PPP \$) }\end{array}$ & $\begin{array}{l}\text { Right to } \\
\text { Food } \\
\text { Index }\end{array}$ & $\begin{array}{c}\text { Right to } \\
\text { Health } \\
\text { Index }\end{array}$ & $\begin{array}{l}\text { Right to } \\
\text { Education } \\
\text { Index }\end{array}$ & $\begin{array}{l}\text { Right to } \\
\text { Housing } \\
\text { Index }\end{array}$ & $\begin{array}{l}\text { Right to } \\
\text { Decent } \\
\text { Work } \\
\text { Index }\end{array}$ & $\begin{array}{c}\text { ESRF-1 } \\
\text { Index }\end{array}$ & $\begin{array}{c}\text { Rank } \\
\text { ESRF-1 } \\
\text { Index }\end{array}$ \\
\hline 1 & Guyana & 2628 & 100.00 & 89.16 & 100.00 & 94.38 & $97.45 ; f$ & 96.20 & 1 \\
\hline 2 & Bulgaria & 10529 & 88.49 & 94.26 & 96.88 & 98.31 & 100.00 & 95.59 & 2 \\
\hline 3 & Cuba & & 100.00 & 99.95 & 85.76 & 93.43 & 98.79 & 95.59 & 3 \\
\hline 4 & Moldova & 2409 & 100.00 & 97.23 & 87.96 & 92.21 & 99.79 & 95.44 & 4 \\
\hline 5 & Kyrgyz Republic & 1894 & 100.00 & 96.51 & 93.24 & 96.90 & 86.29 & 94.59 & 5 \\
\hline 6 & Jordan & 4628 & 96.11 & 95.66 & 91.00 & 90.46 & 99.56 & 94.56 & 6 \\
\hline 7 & Uruguay & 10592 & 79.85 & 96.59 & 98.61 & 100.00 & 96.55 & 94.32 & 7 \\
\hline 8 & Belarus & 10238 & 95.79 & 93.39 & 83.02 & 94.43 & 100.00 & 93.32 & 8 \\
\hline 9 & Chile & 13108 & 99.79 & 98.27 & 80.31 & 89.73 & 96.11 & 92.84 & 9 \\
\hline 10 & Georgia; a & 4403 & $100.00 ; b$ & 91.28 & 84.02 & 96.15 & 86.15 & 91.52 & 10 \\
\hline 11 & Jamaica & 5741 & 100.00 & 92.65 & 80.77 & 84.31 & 99.67 & 91.48 & 11 \\
\hline 12 & Ukraine & 6529 & 76.61 & 91.41 & 94.89 & 93.47 & 99.87 & 91.25 & 12 \\
\hline 13 & Thailand & 7682 & 78.70 & 93.39 & 85.04 & 95.66 & 99.42 & 90.44 & 13 \\
\hline 14 & Brazil & 9034 & 91.18 & 91.93 & 100.00 & 76.10 & 91.48 & 90.14 & 14 \\
\hline 15 & Armenia & 5377 & 83.32 & 93.96 & 88.50 & 93.65 & 89.84 & 89.85 & 15 \\
\hline 16 & Sri Lanka; a & 4007 & 88.44 & 96.41 & 91.81 & 83.83 & 86.82 & 89.46 & 16 \\
\hline 17 & Argentina & 12502 & 88.34 & 94.94 & 81.28 & 88.47 & 91.96 & 89.00 & 17 \\
\hline 18 & Macedonia, FYR & 8350 & 82.91 & 94.60 & 76.16 & 92.00 & 99.31 & 88.99 & 18 \\
\hline 19 & Kazakhstan & 10259 & 72.94 & 88.59 & 92.20 & 94.22 & 95.36 & 88.66 & 19 \\
\hline 20 & Tunisia & 7102 & 82.27 & 90.52 & 86.95 & 85.72 & 96.72 & 88.44 & 20 \\
\hline 21 & Tajikistan & 1657 & 74.36 & 93.50 & 96.10 & 85.25 & 91.69 & 88.18 & 21 \\
\hline 22 & Congo, Dem. Rep.; a & 282 & 84.39 & 88.19 & 100.00 & 66.75 & 100.00 & 87.86 & 22 \\
\hline 23 & Uzbekistan & 2290 & 93.59 & 94.51 & 97.96 & 95.50 & 56.42 & 87.60 & 23 \\
\hline 24 & Albania & 6707 & 62.72 & 98.06 & 77.87 & 95.94 & 98.84 & 86.69 & 24 \\
\hline 25 & Dominican Republic & 6333 & 90.15 & 92.10 & 69.19 & 83.55 & 93.63 & 85.72 & 25 \\
\hline 26 & Romania & 10750 & 82.57 & 93.11 & 85.44 & 68.60 & 98.74 & 85.69 & 26 \\
\hline 27 & Malaysia & 12766 & $75.93 ; b$ & 93.95 & 63.78 & 93.63 & 99.00 & 85.26 & 27 \\
\hline 28 & Algeria; a & 7310 & 79.80 & 90.07 & 78.50 & 85.09 & $91.17 ; f$ & 84.93 & 28 \\
\hline 29 & China & 5084 & 90.60 & 95.30 & 82.65 & 73.69 & 82.33 & 84.92 & 29 \\
\hline 30 & Russian Federation; a & 13873 & $76.18 ; b$ & 90.94 & 71.02 & 85.47 & 99.70 & 84.66 & 30 \\
\hline 31 & Mexico & 13307 & 72.82 & 87.63 & 85.16 & 78.53 & 98.77 & 84.58 & 31 \\
\hline 32 & Egypt, Arab Rep. & 5052 & 71.75 & 81.42 & 88.03 & 79.56 & 97.68 & 83.69 & 32 \\
\hline 33 & Azerbaijan; a & 7414 & 81.05 & 87.83 & 76.19 & 73.13 & 99.96 & 83.63 & 33 \\
\hline 34 & Iran, Islamic Rep. & 10346 & $72.35 ; b$ & 89.10 & 74.00 & 83.14 & 97.57 & 83.23 & 34 \\
\hline 35 & Trinidad and Tobago & 22199 & 93.17 & 85.08 & 58.20 & 83.55 & $92.80 ; f$ & 82.56 & 35 \\
\hline 36 & Colombia; a & 8109 & 78.18 & 92.49 & 86.09 & 79.47 & 76.48 & 82.54 & 36 \\
\hline 37 & Turkey; a & 11825 & 75.42 & 81.32 & 71.05 & 86.99 & 95.10 & 81.98 & 37 \\
\hline 38 & Gambia, The & 1157 & 90.38 & 78.47 & 70.58 & 84.95 & 83.61 & 81.60 & 38 \\
\hline 39 & Mongolia & 3056 & 77.61 & 92.02 & 94.90 & 62.89 & 79.37 & 81.36 & 39 \\
\hline 40 & Paraguay & 4186 & $83.69 ; b$ & 85.30 & 72.68 & 71.65 & 92.72 & 81.21 & 40 \\
\hline 41 & Vietnam & 2455 & 58.39 & 95.55 & 82.01 & 85.02 & 82.13 & 80.62 & 41 \\
\hline 42 & Togo & 744 & 99.47 & 91.41 & 81.82 & 42.07 & 88.33 & 80.62 & 42 \\
\hline 43 & Peru & 7400 & 59.45 & 86.47 & 95.00 & 70.44 & 88.68 & 80.01 & 43 \\
\hline 44 & Venezuela, RB & 11480 & 74.91 & 90.99 & 74.65 & 63.46 & 93.69 & 79.54 & 44 \\
\hline 45 & Ecuador & 7035 & 58.50 & 84.93 & 75.17 & 85.60 & 93.19 & 79.48 & 45 \\
\hline 46 & Suriname & 7378 & 86.00 & 86.34 & 62.12 & 82.05 & $80.56 ; f$ & 79.42 & 46 \\
\hline 47 & Philippines; a & 3217 & 59.94 & 81.43 & 84.08 & 88.61 & 77.41 & 78.29 & 47 \\
\hline 48 & Nicaragua & 2427 & 81.57 & 88.90 & 61.29 & 67.31 & 88.47 & 77.51 & 48 \\
\hline 49 & El Salvador & 5481 & 68.93 & 91.05 & 63.22 & 81.62 & 82.52 & 77.47 & 49 \\
\hline 50 & Morocco & 3880 & 77.02 & 79.19 & 55.79 & 76.85 & 97.30 & 77.23 & 50 \\
\hline 51 & Panama & 10757 & $68.97 ; b$ & 88.81 & 69.78 & 73.57 & 84.12 & 77.05 & 51 \\
\hline
\end{tabular}




\begin{tabular}{|c|c|c|c|c|c|c|c|c|c|}
\hline & Country & $\begin{array}{l}2007 \\
\text { GDP per } \\
\text { capita } \\
\text { (2005 } \\
\text { PPP \$) }\end{array}$ & $\begin{array}{l}\text { Right to } \\
\text { Food } \\
\text { Index }\end{array}$ & $\begin{array}{l}\text { Right to } \\
\text { Health } \\
\text { Index }\end{array}$ & $\begin{array}{l}\text { Right to } \\
\text { Education } \\
\text { Index }\end{array}$ & $\begin{array}{l}\text { Right to } \\
\text { Housing } \\
\text { Index }\end{array}$ & $\begin{array}{l}\text { Right to } \\
\text { Decent } \\
\text { Work } \\
\text { Index }\end{array}$ & $\begin{array}{l}\text { ESRF-1 } \\
\text { Index }\end{array}$ & $\begin{array}{c}\text { Rank } \\
\text { ESRF-1 } \\
\text { Index }\end{array}$ \\
\hline 52 & Liberia; a & 342 & 90.98 & 81.40 & 100.00 & 78.04 & 28.43 & 75.77 & 52 \\
\hline 53 & Indonesia & 3506 & 68.66 & 83.88 & 77.64 & 66.36 & 78.33 & 74.97 & 53 \\
\hline 54 & Ghana & 1260 & 90.01 & 72.95 & 70.27 & 49.11 & 85.68 & 73.60 & 54 \\
\hline 55 & Honduras & 3585 & 64.54 & 81.93 & 63.89 & 75.67 & 81.20 & 73.44 & 55 \\
\hline 56 & Bolivia & 3972 & 58.81 & 74.56 & 88.20 & 63.23 & 78.97 & 72.75 & 56 \\
\hline 57 & Kenya & 1456 & 67.49 & 62.59 & 77.87 & 57.57 & 95.02 & 72.11 & 57 \\
\hline 58 & Guinea-Bissau; a & 451 & 57.97 & 65.70 & 54.36 & 66.90 & 95.84 & 68.15 & 58 \\
\hline 59 & Senegal & 1573 & 99.97 & 72.18 & 30.66 & 58.02 & 74.30 & 67.03 & 59 \\
\hline 60 & Djibouti & 1946 & 54.50 & 76.87 & 20.90 & 89.29 & 89.70 & 66.25 & 60 \\
\hline 61 & Burundi; a & 322 & 19.93 & 76.68 & 99.76 & 91.94 & 38.32 & 65.33 & 61 \\
\hline 62 & Timor-Leste & 677 & 23.97 & 70.73 & 94.64 & 71.20 & 63.59 & 64.83 & 62 \\
\hline 63 & Sierra Leone; a & 641 & 55.51 & 47.60 & 99.34 & 39.19 & 77.53 & 63.83 & 63 \\
\hline 64 & Pakistan & 2357 & 48.55 & 65.61 & 36.33 & 79.80 & 82.28 & 62.51 & 64 \\
\hline 65 & Comoros & 1080 & 35.41 & 91.32 & 48.07 & 71.54 & 64.84 & 62.23 & 65 \\
\hline 66 & Malawi & 719 & 35.10 & 78.60 & 67.49 & 95.83 & 33.75 & 62.15 & 66 \\
\hline 67 & Guatemala & 4308 & 17.78 & 69.03 & 48.54 & 89.14 & 85.67 & 62.03 & 67 \\
\hline 68 & Nepal; a & 991 & 37.92 & 70.76 & 76.52 & 68.87 & 56.01 & 62.02 & 68 \\
\hline 69 & Botswana & 12847 & 52.56 & 73.29 & 65.10 & 58.20 & 57.11; f & 61.25 & 69 \\
\hline 70 & Uganda & 1000 & 69.18 & 65.78 & 44.28 & 59.67 & 62.26 & 60.23 & 70 \\
\hline 71 & Lesotho & 1456 & 44.69 & 65.19 & 59.52 & 65.27 & 66.28 & 60.19 & 71 \\
\hline 72 & Benin & 1239 & 50.65 & 82.05 & 51.41 & 55.07 & 61.09 & 60.06 & 72 \\
\hline 73 & Cote d'Ivoire & 1596 & 67.75 & 61.93 & 27.99 & 57.19 & 85.32 & 60.04 & 73 \\
\hline 74 & Cambodia & 1702 & 46.06 & 68.98 & 62.78 & 51.12 & 69.30 & 59.65 & 74 \\
\hline 75 & Mali & 1023 & 64.86 & 59.49 & 47.68 & 65.72 & 59.06 & 59.36 & 75 \\
\hline 76 & Bangladesh & 1172 & 40.73 & 68.64 & 57.27 & 69.34 & 60.74 & 59.35 & 76 \\
\hline 77 & Mauritania & 1820 & 55.36 & 73.12 & 34.73 & 44.43 & 88.99 & 59.33 & 77 \\
\hline 78 & Cameroon & 2009 & 61.24 & 59.39 & 30.91 & 66.47 & 71.87 & 57.97 & 78 \\
\hline 79 & Namibia & 4868 & 60.65 & 69.73 & 48.39 & 60.46 & $47.46 ; f$ & 57.34 & 79 \\
\hline 80 & India; a & 2600 & 32.93 & 69.30 & 63.93 & 60.46 & 59.26 & 57.18 & 80 \\
\hline 81 & Ethiopia & 736 & 39.30 & 53.00 & 62.37 & 31.26 & 96.77 & 56.54 & 81 \\
\hline 82 & Bhutan & 4568 & $32.38 ; b$ & 65.10 & 43.48 & 65.16 & 72.68 & 55.76 & 82 \\
\hline 83 & Lao PDR & 2044 & 36.57 & 62.80 & 54.65 & 59.42 & 60.98 & 54.89 & 83 \\
\hline 84 & Gabon & 14323 & 51.52 & 62.01 & 25.46 & 43.99 & 90.30 & 54.66 & 84 \\
\hline 85 & Yemen, Rep. & 2205 & 12.23 & 65.47 & 43.18 & 59.96 & 87.34 & 53.64 & 85 \\
\hline 86 & Central African Republic & 674 & 60.11 & 67.60 & 21.16 & 64.60 & 54.08 & 53.51 & 86 \\
\hline 87 & Haiti & 1090 & 86.08 & 68.97 & $15.75 ; \mathrm{d}, \mathrm{e}$ & 43.99 & 51.83 & 53.32 & 87 \\
\hline 88 & Guinea & 1076 & 61.89 & 62.29 & 56.91 & 50.97 & 32.12 & 52.84 & 88 \\
\hline 89 & Congo, Rep.; a & 3316 & 62.58 & 69.59 & 42.92 & 44.12 & 42.39 & 52.32 & 89 \\
\hline 90 & Zambia & 1283 & 28.93 & 51.31 & 72.13 & 67.04 & 39.20 & 51.72 & 90 \\
\hline 91 & Burkina Faso & 1061 & 60.98 & 62.11 & 21.29 & 47.83 & 52.66 & 48.98 & 91 \\
\hline 92 & Madagascar & 881 & 30.43 & 81.07 & 55.90 & 33.65 & 38.96 & 48.00 & 92 \\
\hline 93 & Mozambique; a & 758 & 50.83 & 62.02 & 43.40 & 48.11 & 34.28 & 47.73 & 93 \\
\hline 94 & Swaziland & 4522 & 49.83 & 53.72 & 40.91 & 50.41 & 30.70 & 45.11 & 94 \\
\hline 95 & Tanzania & 1141 & 49.53 & 67.85 & 42.99; e & 52.74 & 6.82 & 43.99 & 95 \\
\hline 96 & Nigeria & 1859 & 47.73 & 44.61 & 49.54 & 41.34 & 35.63 & 43.77 & 96 \\
\hline 97 & Rwanda; a & 818 & 34.03 & 55.82 & 35.81 & 54.49 & 29.17 & 41.86 & 97 \\
\hline 98 & Niger & 592 & 27.71 & 58.32 & 37.47 & 28.58 & 50.89 & 40.59 & 98 \\
\hline 99 & Chad; a & 1395 & 44.81 & 37.24 & 19.17 & 29.10 & 44.77 & 35.02 & 99 \\
\hline 100 & Angola; a & 5085 & 26.46 & 39.13 & $8.49 ; \mathrm{d}$ & 45.98 & 43.42 & 32.69 & 100 \\
\hline 101 & Equatorial Guinea & 28923 & 24.13 & 31.87 & 5.79 & 12.18 & 5.71 & 15.94 & 101 \\
\hline 102 & Andorra & & & & & 100.00 & & . & \\
\hline 103 & Antigua and Barbuda & 17651 & & 94.09 & 94.18 & 85.88 & & & \\
\hline 104 & Bahrain & & $71.16 ; b$ & 93.29 & 100.00 & . & & . & \\
\hline 105 & Bosnia and Herzegovina & 7088 & 86.75 & 96.79 & & 95.91 & 99.78 & . & \\
\hline 106 & Belize & 6359 & 71.11 & 91.39 & 82.54 & 61.51 & & . & \\
\hline 107 & Barbados & & & 96.05 & 85.98 & 100.00 & & & \\
\hline 108 & Brunei Darussalam & 47407 & & 94.47 & 93.93 & & & . & \\
\hline 109 & British Virgin Islands & & & & & 100.00 & & & \\
\hline 110 & Cape Verde & 2871 & & $93.04 ; \mathrm{c}$ & 75.95 & 64.52 & 82.65 & & \\
\hline 111 & Costa Rica & 10239 & & 94.54 & 73.47 & 95.06 & 96.10 & & \\
\hline
\end{tabular}




\begin{tabular}{|c|c|c|c|c|c|c|c|c|c|}
\hline & Country & $\begin{array}{c}2007 \\
\text { GDP per } \\
\text { capita } \\
\text { (2005 } \\
\text { PPP \$) }\end{array}$ & $\begin{array}{l}\text { Right to } \\
\text { Food } \\
\text { Index }\end{array}$ & $\begin{array}{l}\text { Right to } \\
\text { Health } \\
\text { Index }\end{array}$ & $\begin{array}{l}\text { Right to } \\
\text { Education } \\
\text { Index }\end{array}$ & $\begin{array}{l}\text { Right to } \\
\text { Housing } \\
\text { Index }\end{array}$ & $\begin{array}{l}\text { Right to } \\
\text { Decent } \\
\text { Work } \\
\text { Index }\end{array}$ & $\begin{array}{c}\text { ESRF-1 } \\
\text { Index }\end{array}$ & $\begin{array}{c}\text { Rank } \\
\text { ESRF-1 } \\
\text { Index }\end{array}$ \\
\hline 112 & Cyprus & 23499 & . & 97.25 & 94.48 & 100.00 & . & & \\
\hline 113 & Dominica & & . & 96.06 & 94.23 & 86.89 & . & & . \\
\hline 114 & Eritrea; a & 591 & 57.81 & 74.72 & 80.91 & 38.43 & . & & \\
\hline 115 & Estonia & 19327 & . & 94.61 & 99.63 & 94.53 & 100.00 & . & . \\
\hline 116 & Fiji & 4064 & . & 94.52 & 85.75 & 54.72 & . & & . \\
\hline 117 & Micronesia, Fed. Sts. & 2646 & . & 89.64 & & 60.37 & . & . & . \\
\hline 118 & Grenada & 6936 & . & 92.20 & 76.22 & 94.50 & . & & . \\
\hline 119 & Hong Kong, China & 39953 & . & & 75.69 & & . & . & . \\
\hline 120 & Croatia & 14729 & . & 96.88 & 75.48 & 97.99 & 100.00 & & . \\
\hline 121 & Israel & 24824 & . & & 87.78 & & . & . & . \\
\hline 122 & Kiribati & 1223 & . & 95.70 & 100.00 & 57.26 & . & & . \\
\hline 123 & St. Kitts and Nevis & 13675 & . & 92.49 & 92.19 & 95.20 & . & . & . \\
\hline 124 & Kuwait & & $30.50 ; b$ & 94.53 & 53.16 & & . & & . \\
\hline 125 & Lebanon & 9546 & 76.71 & 91.13 & 56.73 & 98.37 & . & . & . \\
\hline 126 & Libya & 13565 & . & 94.39 & & 74.36 & . & & . \\
\hline 127 & St. Lucia & 9242 & . & 95.57 & 93.23 & 90.13 & 69.70; f & . & . \\
\hline 128 & Liechtenstein & & . & & 100.00 & & . & & . \\
\hline 129 & Lithuania & 16659 & . & 93.47 & 84.53 & & 99.15 & . & . \\
\hline 130 & Latvia & 16317 & . & 93.63 & 83.56 & 79.07 & 100.00 & & . \\
\hline 131 & Macao, China & 54134 & . & . & 98.24 & & . & & . \\
\hline 132 & Monaco & & . & & & 100.00 & . & & . \\
\hline 133 & Maldives & 4907 & 60.45 & 85.12 & 87.61 & 67.17 & . & . & . \\
\hline 134 & Marshall Islands & & . & 82.78 & 81.00 & 79.68 & . & & . \\
\hline 135 & Malta & 22046 & . & 98.45 & 95.49 & . & . & . & . \\
\hline 136 & Myanmar; a & & 63.96 & 92.15 & 98.57 & 95.52 & . & & . \\
\hline 137 & Montenegro & 10363 & 89.64 & 95.49 & . & 91.25 & . & . & . \\
\hline 138 & Montserrat & & . & & . & 100.00 & . & & . \\
\hline 139 & Mauritius & 10668 & $83.11 ; b$ & 93.78 & 76.52 & 95.02 & . & . & . \\
\hline 140 & Niue & & . & & . & 100.00 & . & & . \\
\hline 141 & Oman & . & $75.40 ; b$ & 92.81 & 69.72 & 69.63 & . & . & . \\
\hline 142 & Palau & & . & 92.33 & 100.00 & 69.30 & . & & . \\
\hline 143 & Papua New Guinea & 1968 & . & 65.23 & 23.39; e & 46.77 & $65.22 ; f$ & & . \\
\hline 144 & Qatar & & . & 89.20 & 100.00 & 100.00 & . & & . \\
\hline 145 & Saudi Arabia & 21659 & 49.33; b & 86.91 & 76.11 & 93.12 & . & . & . \\
\hline 146 & Sudan; a & 1970 & 38.42 & 65.30 & 32.68 & 57.10 & . & & . \\
\hline 147 & Singapore & 46939 & 91.73 & 98.46 & . & 100.00 & . & & . \\
\hline 148 & Solomon Islands & 1629 & . & 74.72 & $45.23 ; d$ & 57.04 & . & & . \\
\hline 149 & Serbia; a & 10128 & 89.27 & 95.36 & . & 92.83 & . & . & . \\
\hline 150 & Sao Tome and Principe & 1547 & 83.73 & 88.52 & 61.78 & 60.69 & . & & . \\
\hline 151 & Slovenia & 26294 & . & 97.40 & 90.68 & . & 100.00 & & . \\
\hline 152 & Seychelles & 15482 & . & & 100.00 & & . & & . \\
\hline 153 & Syrian Arab Republic & 4260 & 65.34 & 94.97 & 80.85 & 89.62 & . & & . \\
\hline 154 & Turkmenistan & & 80.62 & & . & 66.11 & . & & . \\
\hline 155 & Tonga & 3539 & . & 97.08 & 95.74 & 99.52 & . & & . \\
\hline 156 & United Arab Emirates & & $41.18 ; b$ & 95.96 & 79.30 & 94.53 & . & & . \\
\hline 157 & $\begin{array}{l}\text { St. Vincent and the Grena } \\
\text { dines }\end{array}$ & 7263 & . & 94.49 & 69.49 & & . & & . \\
\hline 158 & Vanuatu & 3462 & . & 91.48 & 53.76 & 55.49 & . & & . \\
\hline 159 & West Bank and Gaza & & 94.15 & 97.46 & 91.32 & 83.41 & . & & . \\
\hline 160 & Samoa & 4218 & . & 95.68 & 84.99 & 93.42 & . & & . \\
\hline 161 & South Africa & 9215 & . & 70.99 & 75.62 & 65.98 & 62.82 & & . \\
\hline $\begin{array}{l}\text { Tota } \\
\text { l }\end{array}$ & $\mathrm{N}$ & 142 & 121 & 150 & 149 & 149 & 112 & 101 & 101 \\
\hline
\end{tabular}

a. Conflict Country: Data on at least one indicator from period within 10 years of a major conflict. (Uppsala Conflict Data Program and the International Peace Research Institute, 2008).

b. Data on Low Height for Age pre-2000.

c. Data on Births Attended by Skilled Health Workers pre-2000.

d. Data on Primary School Completion Rate pre-2000.

e. Data on Gross Secondary School Enrollment Rate pre-2000.

f. Data on Absolute Poverty (<\$1.25 2005 PPP per day) Rate pre-2000. 
Table 6

ESRF-2 Index and Component Rights

\begin{tabular}{|c|c|c|c|c|c|c|c|c|}
\hline & Country & $\begin{array}{c}2007 \text { GDP } \\
\text { per capita } \\
(2005 \\
\text { PPP\$) }\end{array}$ & $\begin{array}{l}\text { Right to } \\
\text { Health } \\
\text { Index }\end{array}$ & $\begin{array}{l}\text { Right to } \\
\text { Food } \\
\text { Index }\end{array}$ & $\begin{array}{l}\text { Right to } \\
\text { Education } \\
\text { Index }\end{array}$ & $\begin{array}{l}\text { Right to } \\
\text { Work } \\
\text { Index }\end{array}$ & $\begin{array}{c}\text { ESRF-2 } \\
\text { Index }\end{array}$ & $\begin{array}{c}\text { Rank } \\
\text { ESRF-2 } \\
\text { Index }\end{array}$ \\
\hline 1 & Finland & 33324 & 96.99 & 96.55 & 100.00 & 85.09 & 94.66 & 1 \\
\hline 2 & Netherlands & 36956 & 96.96 & 93.52 & 93.05 & 89.19; a & 93.18 & 2 \\
\hline 3 & Sweden & 34090 & 98.45 & 96.83 & 87.27 & 88.94 & 92.87 & 3 \\
\hline 4 & Denmark & 34905 & 95.74 & 93.89 & 87.49 & 88.92 & 91.51 & 4 \\
\hline 5 & Czech Republic & 22953 & 95.54 & 91.49 & 85.31 & 89.16; a & 90.38 & 5 \\
\hline 6 & Norway & 49359 & 97.14 & 94.00 & 81.29 & 86.01 & 89.61 & 6 \\
\hline 7 & Austria & 35537 & 97.18 & 89.38 & 88.37 & 82.36 & 89.32 & 7 \\
\hline 8 & Canada & 36260 & 97.09 & 92.07 & 93.81 & 72.82 & 88.95 & 8 \\
\hline 9 & Australia & 32735 & 97.96 & 91.48 & 92.34 & 73.65 & 88.86 & 9 \\
\hline 10 & France & 31625 & 98.26 & 90.72 & 85.94 & 79.93 & 88.71 & 10 \\
\hline 11 & Poland & 15634 & 94.45 & 93.87 & 94.90 & 71.36; a & 88.64 & 11 \\
\hline 12 & Hungary & 17894 & 92.26 & 90.09 & 85.16 & 85.66 & 88.29 & 12 \\
\hline 13 & Belgium & 33399 & 97.40 & 88.14 & 90.35 & 76.15 & 88.01 & 13 \\
\hline 14 & Japan & 31689 & 99.68 & 84.04 & 93.37 & 73.92; a & 87.76 & 14 \\
\hline 15 & Germany & 33181 & 97.04 & 90.43 & 89.07 & 73.25 & 87.45 & 15 \\
\hline 16 & Switzerland & 37581 & 98.28 & 89.98 & 77.25 & 81.50 & 86.75 & 16 \\
\hline 17 & Slovak Republic & 19342 & 92.72 & 91.95 & 84.18 & 76.83; a & 86.42 & 17 \\
\hline 18 & United Kingdom & 33717 & 96.20 & 88.89 & 83.84 & 73.17 & 85.52 & 18 \\
\hline 19 & Spain & 28536 & 98.42 & 90.17 & 84.09 & 68.49 & 85.29 & 19 \\
\hline 20 & Ireland & 41036 & 96.41 & 94.54 & 86.82 & 62.89 & 85.17 & 20 \\
\hline 21 & Italy & 28682 & 98.99 & 91.05 & 80.54 & 68.83 & 84.85 & 21 \\
\hline 22 & Greece & 26928 & 97.63 & 86.59 & 80.74 & 65.92 & 82.72 & 22 \\
\hline 23 & Luxembourg & 72783 & 95.92 & 93.14 & 68.29 & 72.80 & 82.54 & 23 \\
\hline 24 & United States & 43055 & 93.77 & 85.43 & 67.89 & 60.79 & 76.97 & 24 \\
\hline 25 & Iceland & 36118 & 98.78 & 98.44 & 85.79 & . & . & . \\
\hline 26 & Korea, Rep. & 23399 & 97.14 & 96.90 & 91.80 & . & . & . \\
\hline 27 & New Zealand & 25281 & 97.62 & 93.72 & 93.81 & . & . & . \\
\hline 28 & Portugal & 21169 & 97.12 & 90.90 & 79.30 & & & \\
\hline Total & 28 & 28 & 28 & 28 & 28 & 24 & 24 & 24 \\
\hline
\end{tabular}

a. Data on relative poverty rate ( $<50 \%$ median income) pre-2000. 
Table 7: Common HDI Values Widely Differing ESRF Values

\begin{tabular}{|c|c|c|c|c|}
\hline Country & 2007 GDP per capita (2005 PPP\$) & $2006 \mathrm{HDI}$ & ESRF & Rank \\
\hline The Gambia & 1157 & .471 & 81.6 & 38 \\
\hline Benin & 1239 & .459 & 60.06 & 72 \\
\hline Tanzania & 1141 & .503 & 43.99 & 95 \\
\hline Senegal & 1573 & .502 & 66.25 & 60 \\
\hline Ghana & 1260 & .533 & 73.60 & 54 \\
\hline Madagascar & 881 & .533 & 48.00 & 92 \\
\hline Equatorial Guinea & 28923 & .717 & 15.94 & 101 \\
\hline Moldova & 2409 & .719 & 95.44 & 4 \\
\hline Jordan & 4628 & .769 & 94.56 & 6 \\
\hline Turkey & 11825 & .798 & 81.98 & 37 \\
\hline Bulgaria & 10529 & .834 & 95.59 & 2 \\
\hline Panama & 10757 & .832 & 77.05 & 51 \\
\hline Uruguay & 10592 & .859 & 94.32 & 7 \\
\hline Argentina & 11825 & .798 & 81.98 & 37 \\
\hline Finland & 33324 & .954 & 94.66 & 1 \\
\hline United States of America & 43055 & .950 & 76.97 & 24 \\
\hline
\end{tabular}


Table 8: Mapping Indicators and Measurement Approaches-Contrasting Stylized Features

\begin{tabular}{|c|c|c|c|c|}
\hline Type of Human Rights Indicator & $\begin{array}{l}\text { ESRF } \\
\text { Index }\end{array}$ & $\begin{array}{l}\text { Conventional HR Reporting Without } \\
\text { 'Indicators' } \\
\text { e.g. ESCR Committee Reports }\end{array}$ & $\begin{array}{l}\text { Recent proposals: } \\
\text { Backman et al, Right to Health; } \\
\text { FIAN \& Manneheim, Right to Food; } \\
\text { COHRE Right to Housing }\end{array}$ & OHCHR Indicators \\
\hline \multicolumn{5}{|l|}{ Type of obligation } \\
\hline Structural e.g. institutionaled guarantees & & $\mathbf{X}$ & $\mathbf{x}$ & $\mathbf{x}$ \\
\hline Process e.g. participation and non-discrimination & & $\mathbf{x}$ & $\mathbf{X}$ & $\mathbf{x}$ \\
\hline Outcome - human outcome data & $\mathbf{x}$ & $\mathbf{x}$ & $\mathbf{x}$ & $\mathbf{x}$ \\
\hline Outcome - progressive realization data & $\mathrm{x}$ & & & \\
\hline Negative obligations: to respect and protect $\mathrm{Y} / \mathrm{N}$ & & $\mathbf{x}$ & $\mathbf{X}$ & $\mathbf{X}$ \\
\hline Positive obligations: to fulfill - data & $\mathbf{x}$ & & & \\
\hline \multicolumn{5}{|l|}{ Level of aggregation } \\
\hline $\begin{array}{l}\text { Summary, aggregate national level, disaggregated } \\
\text { national groups }\end{array}$ & $\mathbf{x}$ & & & $\mathbf{x}$ \\
\hline $\begin{array}{l}\text { Summary, aggregate across rights, disaggregated } \\
\text { specific rights }\end{array}$ & $\mathbf{x}$ & & & \\
\hline \multicolumn{5}{|l|}{ Units of analysis } \\
\hline $\begin{array}{l}\text { Intra country, inter-country and inter-temporal } \\
\text { comparisons }\end{array}$ & $\mathbf{x}$ & & & $\mathbf{x}$ \\
\hline Individual cases & & $\mathbf{x}$ & & \\
\hline
\end{tabular}


